Historic, archived document

Do not assume content reflects current scientific knowledge, policies, or practices. 



\section{4}

\section{Kelsey's Hardy American Trees, Shrubs and Plants}

Rhododendrons

Azaleas

Mountain Laurel

Leucothoe

Andromedas

Specimen Conifers, Etc.

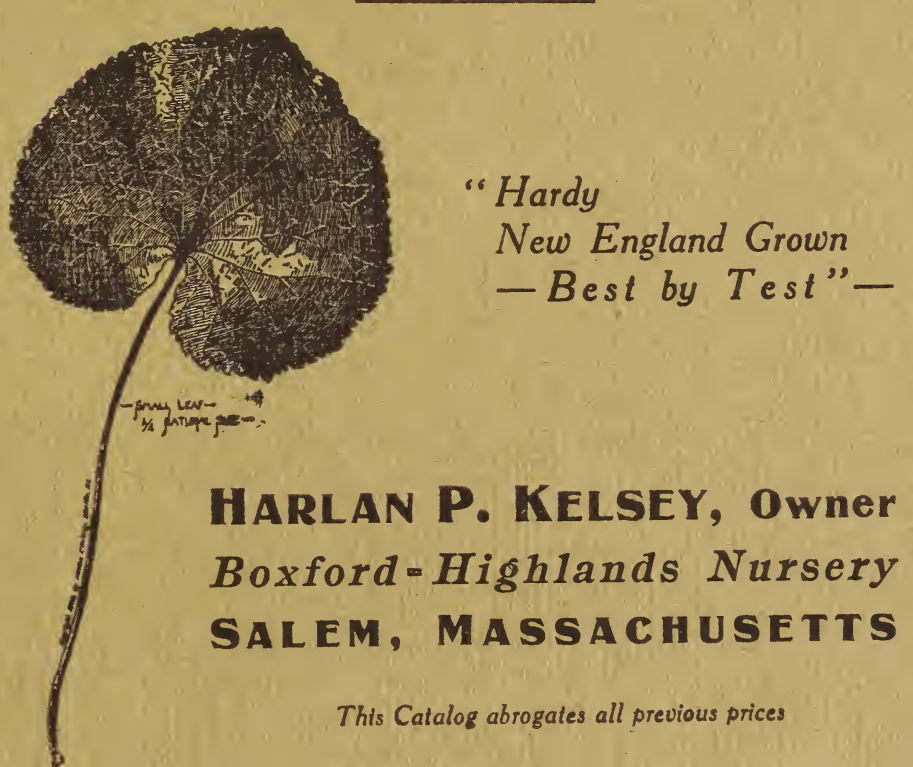





\section{BOXFORD-HIGHLANDS NURSERY}

Hardy Native American Plants and Specimen Evergreens are Specialties at Boxford-Highlands Nursery, backed by over thirty years' experience. Many of our choicest American ornamentals have been introduced to cultivation by me, including Carolina Hemlock, Azalea vaseyi, Rhododendron carolinianum, Lilium grayi, Shortia galacifolia, Robinia kelseyi, Rhododendron catawbiense compacta, and many others.

Shipping Season begins in Spring, when frost leaves the ground, usually March 15 to June 1st. August planting of Specimen Evergreens-Rhododendrons, Kalmias, Leucothoes, Conifers and many Bulbs and Herbaceous Plants-has proved most successful, general stock going out again from September to December.

Shipping Instructions should be given, otherwise I use my best judgment, but assume no risk. All shipments travel at purchaser's risk and carriers must be held liable for any damage in transit. All stock becomes the property of the purchaser on delivery to transportation company or carrier.

Truck Delivery. Where the size of order warrants, there are distinct advantages in auto-truck delivery for distances up to 30 to 50 miles, and we have made large deliveries up to 200 miles. Stock arrives quickly and when wanted, and is delivered fresh on the grounds, saving local trucking and unpacking. Charges are made according to size of truck and distance traveled.

Prices are made to fit the quality of the stock sent out. Discriminating buyers now realize that the greatest value of nursery stock is underground. Frequent transplanting and handling specimens with adequate burlaped balls, means success and quick results. It costs more, but it is the fixed policy of the Boxford-Highlands Nursery, and "cheap" stock will not be handled or sent out. The best is always the cheapest.

Special Selection. Stock specially selected at Nursery or ordered by mail will be charged at advance prices to fit the value of stock selected. The prices in this catalog cover the average good grade as they run in the nursery row.

Packing Charges. At prices printed in this catalog, boxing, balling or burlaping is free, except where noted. Where small sizes or deciduous stock is balled and burlaped by special request or to the "Trade," a charge is always made to cover cost, as follows:
Burlaping Charges:
Each

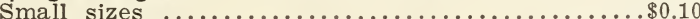

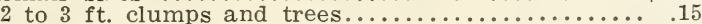

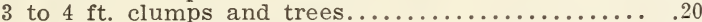

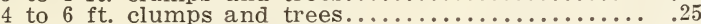

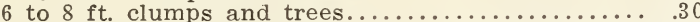

Larger sizes are billed in proportion. Where large evergreens are shipped on "platforms," a suitable charge will be made to cover cost.

Terms. Cash or satisfactory reference from unknown customers. All accounts are due the first of each month, unless by special arrangement. Five at 10 rate; 50 at 100 rate: 500 at 1,000 rate. 5 per cent discount may be deducted when cash accompanies order. When not taken, extra plants will be sent to cover such discount.

Non-Warranty. No guarantee, express or implied, is made that stock will grow, whether planted by me or otherwise. Having no control over after-treatment of plantings or over weather conditions, it is obvious that purchaser must assume all responsibility after stock leaves the Nursery in good condition. However, under certain conditions I am prepared to guarantee plantings made by me covering a specified period, on an insurance basis. Charges will be made according to the risk involved and value of material.

Claims for errors must be made on receipt of goods. If there is any mistake or fault on my part it will be gladly rectified.

Quarantine. The Federal Horticultural Board has proclaimed a practically complete embargo on all Foreign Trees and Shrubs and most Herbaceous Plants. Americans are now learning that our Native Trees and Plants are hardier, freer from disease, more permanent, and far more beautiful and "fitting" in our landscapes and home grounds than exotic material. Still the best exotics can and now will be grown in America for Americans. We are growing them by thousands. 
KELSEY'S HARDY AMERICAN PLANTS

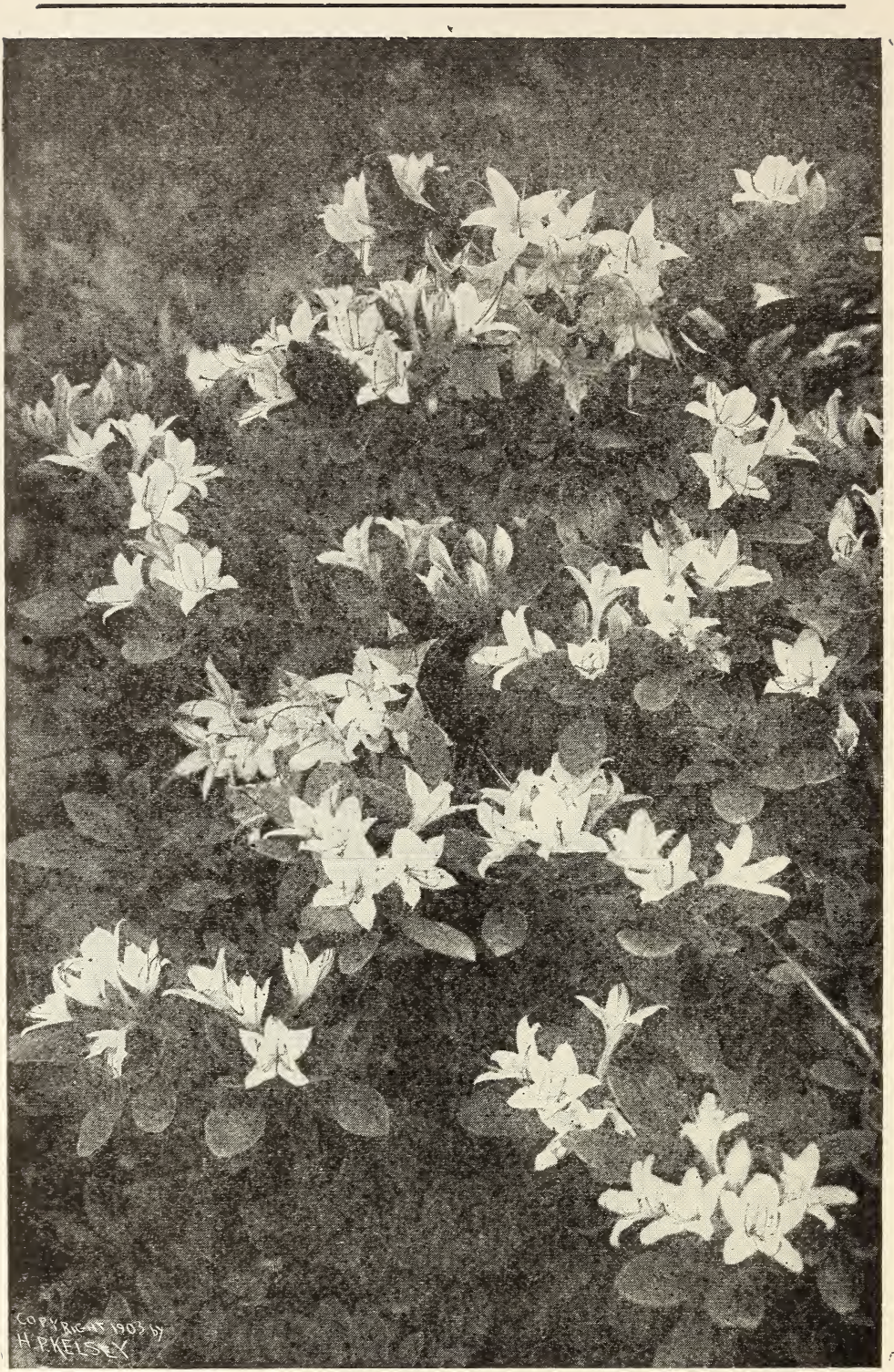

AZALEA ARBORESCENS, Sweet Azalea.

Photographed in Franklin Park, from stock supplied by Boxford-Highlands Nursery. 


\section{LANDSCAPE DEPARTMENT}

Planning and Planting, and the Use of Hardy Native Plants

The successful carrying out of any landscape improvement depends to so great an extent upon the knowledge, skill, and good taste of the one to whom this work is intrusted, that it is supremely important to start right, no matter whether the work be large or small.

By the employment of a trained landscape architect expensive experiments may be avoided and successful results insured. This applies to questions both of design and of practical planting.

There are so many well-trained landscape architects today that there is little excuse for anyone not having the joys that come from well-executed work, based on plans that properly fit each case.

The undersigned takes charge of the laying out and planting of large and small grounds, extensive estates, parks, cemeteries, and other public or private landscape improvements. Particular attention is given to the use of hardy American plants, which are unquestionably the basis of all the best permanent plantings in this country, and particularly where naturalistic effects are desired. If this fact is ignored, the most finished and lasting results cannot be secured. The formal garden, where in the past exotics have been used almost exclusively, has wonderful possibilities for the employment of native plants, and especially our magnificent Rhododendrons, Kalmias, and other broadleaf evergreens, as well as Junipers, Hemlocks, Pines and other Conifers. These plants are not only absolutely hardy and unusually free from foreign diseases and pests, but show splendid summer and winter effects that can be produced in no other way. There are, in fact, no foreign plants which can adequately take their place.

Horticultural knowledge, including soil requirements and an intimate acquaintance with plant material, is quite as essential as and co-ordinate with proper designing,-facts too often overlooked. Moreover, water-color sketches do not constitute landscape gardening. It is an art to be practised only after years of study and experience, and, like painting and sculpture, must be born in one and cannot be altogether acquired.

We are not committed to the use of Native Plants exclusively, and, mhere useful and advisable, always introduce the best exotics to produce desired results.

The undersigned is prepared to make professional visits for consultation and advice, to make surveys, plans and designs, and to undertake the entire construction, planting, and carrying out of landscape Tork of all descriptions.

The wild garden, the rockery, and the bog and water garden offer possibilities in the way of interest, distinctiveness and variety that are often almost wholly overlooked or but meagerly taken advantage of.

The mountain or seashore bungalow, the modest town home, and the pretentious estate must each have a treatment suitable to particular needs, though in every case a development should prevail that makes the most of striking natural features or topography, giving to each a character of its own.

Lack of time, distance, and other conditions may sometimes lead customers to desire a local landscape architect. I know the leading members of the profession, and at any time on request will gladly recommend landscape architects who may be safely trusted with any commission, large or small.

Landscape Forestry. We do Landscape Forestry, treating woodlands from a landscape standpoint as well as for commercial uses. Our Landscape Department plans and plants large or small estates. Mr. Kelsey is open for consultations and engagements.

Correspondence with those having new grounds to lay out and plant, or unsatisfactory old grounds to make over, is solicited. Charges are reasonable, yet sufficient to warrant the best results in fairness to my clients and myself.

HARLAN P. KELSEY, Landscape Department, Telephone Connection. Hawthorne Building, Salem, Massachusetts, 


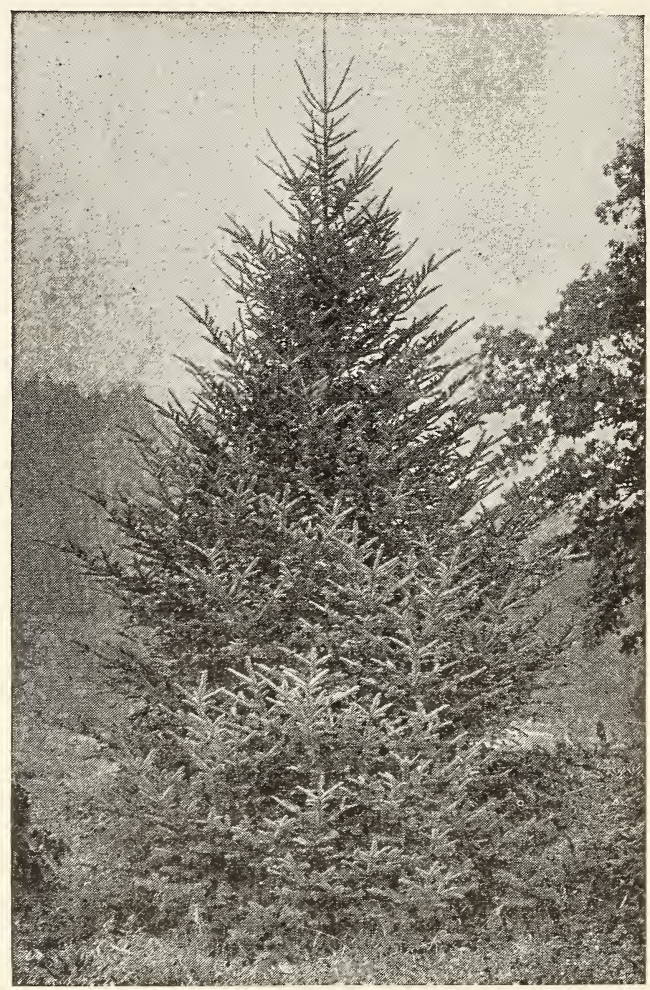

ABIES FRASERI, Fraser Fir, as a specimen.

A fine species from the high Carolina Mountains and far superior to the northern "Balsam Fir. 


\section{HARDY CONIFERS AND OTHER EVERGREENS}

\section{THE FIRS, Abies}

ABIES CONCOLOR, White Fir.

$\begin{array}{rcrr} & \text { Each } & 10 & 100 \\ 12-18 \text { in. } & \$ 1.50 & \$ 12.00 & \$ 115.00 \\ 18-24 \text { in. } & 2.50 & 22.50 & 210.00 \\ 2-3 \text { ft. } & 4.00 & 36.00 & 330.00 \\ 3-4 \mathrm{ft} . & 6.00 & 54.00 & \end{array}$

Extra Specimens, 9-18 ft., $\$ 10.00$ to $\$ 150.00$ each

ABIES FRASERI, Fraser Fir.

A fine species from the Carolina Mountains and far superior to the Northern Balsam Fir.

$\begin{array}{rrrrr}12-18 \text { in. } & .60 & 5.40 & 45.00 \\ 18-24 \text { in. } & 1.00 & 9.00 & 81.00 \\ \text { Specimens } 6-7 \text { ft. } & 7.00 & 66.00 & 600.00 \\ 7-8 \text { ft. } & 9.00 & 84.00 & 780.00 \\ 8-9 & \mathrm{ft} . & 12.00 & 105.00 & \end{array}$

Extra Specimens, 9-14 ft., $\$ 15.00$ to $\$ 50.00$ each

ABIES FIRMA, MOMI Fir. 6-9 in.

$\begin{array}{ll}.60 & 5.40\end{array}$

ABIES HOMOLEPSIS (brachyphylla), Nikko Fir.

$\begin{array}{rrr}18-24 \text { in. } & 3.00 & 27.00 \\ 2-3 \mathrm{ft} . & 4.50 & 42.00 \\ 3-4 \mathrm{ft} . & 6.00 & 54.00 \\ 5-6 \mathrm{ft} . & 8.00 & 72.00\end{array}$

ABIES HOMOLEPSIS UMBILICATA (umbellata), Dimplecone Fir. ABIES PECTINATA, Silver Fir. $5-9 \mathrm{ft}$. $\quad \$ 7.00$ to $\$ 15.00$ each

$\begin{array}{lrrr}\text { ABIES PECTINATA, Silver Fir. } & & & \\ \text { ABIES VEITCHI, Veitch Fir. } & 18-24 \mathrm{in} . & 3.50 & \\ & 2-3 \mathrm{ft} . & 4.50 & 42.00 \\ 3-4 & \mathrm{ft} . & 6.00 & 54.00 \\ 4-5 & \mathrm{ft} . & 9.00 & \\ & 6-7 \mathrm{ft} . & 12.00 & \end{array}$

Larger Specimens up to $\$ 100.00$ each

ANDROMEDA POLIFOLIA. See under Broadleaf Evergreens.

ARCTOSTAPHYLOS UVAURSI. See under Broadleaf Evergreens.

\section{THE CYPRESS AND RETINOSPORA, Chamaecyparis}

CHAMAECYPARIS OBTUSA NANA, Dwarf Hinoki Cypress.

$$
\text { 12-18 in. } \quad 3.50
$$

CHAMAECYPARIS PISIFERA, Sawara Retinospora.

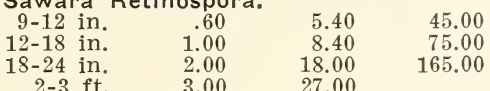
DAPHNE CNEORUM. See under Broadleaf Evergreens.

ILEX OPACA, American Holly.
12-18 in.
1.50
13.50

\section{THE JUNIPERS AND REDCEDARS, Juniperus}

JUNIPERUS CHINENSIS PFITZERIANA, Pfitzer Juniper

$\begin{array}{rrr}6-9 \text { in. } & \text { Each } & 10 \\ 8-12 \text { in. } & 2.25 & 11.25 \\ 12-18 \text { in. } & 3.00 & 18.00 \\ 18-24 \text { in. } & 4.00 & 27.00 \\ & 36.00\end{array}$

JUNIPERUS COMMUNIS DEPRESSA, Prostrate Juniper.

The beautiful New England type and the best of ground covers.

Very hardy and thrives in light or heavy soils.

$\begin{array}{rrrr}9-12 \text { in. } & 1.00 & 9.00 & 75.00 \\ 12-18 \text { in. } & 1.50 & 12.00 & 105.00 \\ 18-24 \text { in. } & 2.00 & 18.00 & 162.00\end{array}$




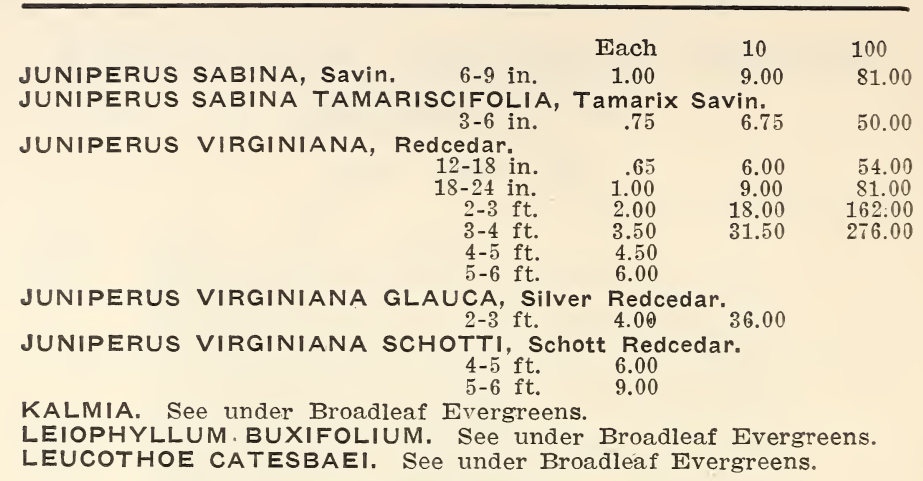

\section{THE SPRUCES, Picea}

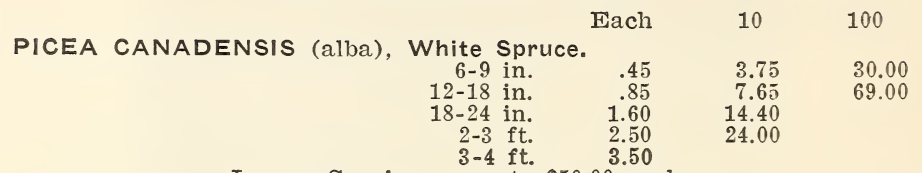

Larger Specimens up to $\$ 50.00$ each.

\section{PICEA CANADENSIS CAERULEA, Silver White Spruce.}

PICEA ENGELMANNI, Engelmann Spruce.

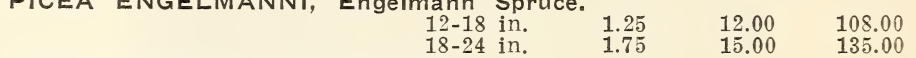

PICEA EXCELSA, Norway Spruce.

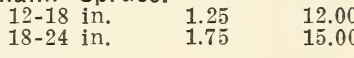

$\begin{array}{rrrr}18-24 \text { in. } & .75 & 6.00 & 54.00 \\ 2-3 \text { ft. } & 1.60 & 14.40 & 127.00\end{array}$

PICEA KOYAMAI, Koyamai spruce.
A beautiful rare Japanese species.

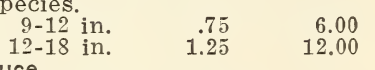

PICEA OMORIKA, Serbian Spruce.

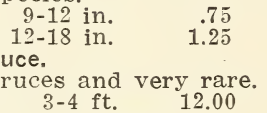

PICEA PUNGENS (parryana), Colorado spruce.

This is a typical green form.

$\begin{array}{rcr}12-18 \text { in. } & 1.00 & 9.00 \\ 18-24 \text { in. } & 1.50 & 13.50 \\ 2-3 \mathrm{ft} . & 2.50 & 24.00 \\ 3-4 \mathrm{ft} . & 4.00 & 36.00\end{array}$

81.00

129.00

210.00

$$
\text { 7-15 ft. Specimens up to } \$ 75.00 \text { each. }
$$

PICEA PUNGENS GLAUCA, Blue Colorado Spruce.

Selected from seedling types but not grafted.

$\begin{array}{rr}\text { but not } & \text { grafted. } \\ 12-18 \text { in. } & 2.75 \\ 18-24 \text { in. } & 3.60 \\ 2-3 \text { ft. } & 5.20 \\ 3-4 \text { ft. } & 7.50 \\ \text { ens up to } & \$ 90.00 \text { eac }\end{array}$

6-18 ft. Specimens up to $\$ 90.00$ each.

PICEA PUNGENS KOSTERI, Koster BIUe Spruce.

These are true Koster variety and perfect specimens in every respect.

$$
\begin{array}{rrr}
7-8 \mathrm{ft} . & 60.00 & 540.00 \\
8-9 \mathrm{ft} . & 75.00 & 675.00 \\
9-10 \mathrm{ft} . & 90.00 & 810.00 \\
10-12 \mathrm{ft} . & 120.00 & 1080.00 \\
4-5 \mathrm{ft} . & 3.50 & 30.00
\end{array}
$$

PICEA RUBRA, Red Spruce. $4-5 \mathrm{ft}$.
PIERIS FLORIBUNDA. See under Broadleaf Evergreens. 


\section{THE PINES, Pinus}

PINUS BANKSIANA, Jack Pine.

$2-3 \mathrm{ft}$.
$3-4 \mathrm{ft}$
$4-5 \mathrm{ft}$.
$5-6 \mathrm{ft}$.
$6-8 \mathrm{ft}$.
$8-10 \mathrm{ft}$.

Each

$10 \quad 100$

.75

1.50

2.50

3.50

5.00

8.00

6.00

45.00

12.00

108.00

$21.00 \quad 180.00$

$30.00 \quad 270.00$

$45.00 \quad 405.00$

PINUS CEMBRA, Swiss Stone Pine.

$12-18$ in.

18-24 in.

PINUS DENSIFLORA, Japanese Red Pine.

1.7515 .0 ก

$2.50 \quad 22.50$

$3.50 \quad 31.50$

$2-3 \mathrm{ft}$.

PINUS EDULIS, Nut Pine.

$5-6 \mathrm{ft}$.

$1.75 \quad 15.00$

$4.00 \quad 36.00$

$.50 \quad 4.50$

PINUS FLEXILIS, Limber Pine.

$3-6$ in.

$12-18 \mathrm{in}$.
$18-24 \mathrm{in}$.
$2-3 \mathrm{ft}$.
$3-4 \mathrm{ft}$.
$4-5 \mathrm{ft}$.

.75

1.00

2.00

3.00

405.00
600.00

PINUS MONTANA, Swiss Mountain Pine.

$\begin{array}{lrr}2-3 \mathrm{ft} . & 4.00 & 36.00 \\ 3-4 \mathrm{ft} . & 8.00 & 72.00 \\ 4-5 \mathrm{ft} . & 12.50 & 120.00\end{array}$

PINUS MONTANA MUGHUS. Mugho Pine.

Perhaps the most useful of the dwarf planting.

$6-12$ in.
$12-18$ in.
$18-24$ in.
$2-3 \mathrm{ft}$.
$3-4 \mathrm{ft}$.

conifers

$1.25 \quad 12.00 \quad 108.00$

$\begin{array}{lll}1.60 & 15.00 & 135.00\end{array}$

$\begin{array}{lll}2.40 & 22.50 & 210.00\end{array}$

$\begin{array}{lll}4.50 & 42.00 & 378.00\end{array}$

$8.00 \quad 72.00$

PINUS MONTICOLA, Western White Pine. $2-3 \mathrm{ft}$.

PINUS NIGRA, Austrian PIne. $3-4 \mathrm{ft}$.

108.00

162.00

$$
\begin{array}{r}
\text { 6-12 in. } \\
12-18 \text { in. } \\
18-24 \mathrm{in} . \\
2-3 \mathrm{ft} . \\
3-4 \mathrm{ft} . \\
4-5 \mathrm{ft} .
\end{array}
$$

PINUS PARVIFLORA, Japanese White Pine.

18-24 in.

PINUS PONDEROSA, Western Yellow Pine.

.60
1.25

5.40

12.00

2.00

3.00

18.00

27.00

4.50

40.5 日

6.00

48.00

255.00

2.00

$$
\begin{gathered}
18-24 \mathrm{in} . \\
2-3 \mathrm{ft} . \\
3-4 \mathrm{ft} . \\
4-5 \mathrm{ft} .
\end{gathered}
$$

1.00

2.00

3.00

5.00

54.00

PINUS RESINOSA, Red Pine.

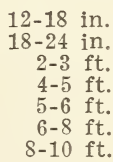

$$
\begin{array}{r}
.75 \\
1.25 \\
1.75 \\
6.00 \\
8.00 \\
10.00 \\
15.00
\end{array}
$$

$\begin{array}{rr}9.00 & 81.00 \\ 18.00 & 162.00 \\ 27.00 & 240.00 \\ 45.00 & \end{array}$

PINUS STROBUS, White Pine.

$6-9 \mathrm{in}$.
$2-3 \mathrm{ft}$.
$3-4 \mathrm{ft}$.
$4-5 \mathrm{ft}$.
$5-6 \mathrm{ft}$.
$6-8 \mathrm{ft}$.
$8-10 \mathrm{ft}$.


PINUS SYLVESTRIS, Scotch Pine

$$
\begin{array}{crcc} 
& & \text { Each } & 10 \\
\text { Specimens } & 8-10 \mathrm{ft} . & 10.00 & 90.00 \\
\text { Specimens } & 10-12 \mathrm{ft} & 12.50 & 112.50 \\
\text { Extra Specimens, } \$ 15.00 \text { to } & \$ 30.00 \text { each. } &
\end{array}
$$

PINUS THUNBERGI, Japanese Black Pine.

$$
\begin{array}{lll}
2-3 \mathrm{ft} & 2.00 & 18.00 \\
3-4 \mathrm{ft} & 3.00 & 27.00
\end{array}
$$

PSEUDOTSUGA DOUGLASI, Douglas-fir.

$\begin{array}{rrr}6-9 \text { in. } & .30 & 2.40 \\ 9-12 \text { in. } & .60 & 5.40 \\ 12-18 \text { in. } & 1.00 & 9.00 \\ 18-24 \text { in. } & 1.50 & 13.50 \\ 2-3 \text { ft. } & 2.25 & 21.00 \\ 3-4 \text { ft. } & 3.00 & 27.00 \\ 4-5 \text { ft. } & 5.00 & 45.00 \\ 5-6 \text { ft. } & 7.00 & 63.00\end{array}$

Larger Specimens up to $\$ 40.00$ each.

PSEUDOTSUGA DOUGLASI GLAUCA, Blue Douglas-fir.

7-8 ft. $\quad 12.00$

RHODODENDRONS. See under Broadleaf Evergreens.

SCIADOPITYS VERTICILLATA, Umbrella-pine.

$$
\begin{array}{rr}
9-12 \text { in. } & 1.50 \\
12-18 \text { in. } & 2.50
\end{array}
$$

\section{THE YEWS, Taxus}

TAXUS BACCATA REPANDENS, Spreading English Yew.

$$
\begin{array}{rrr} 
& \text { Each } & 10 \\
15-18 \text { in. } & 3.00 & 27.00 \\
18-24 \text { in. } & 5.00 & 45.00
\end{array}
$$

TAXUS CANADENSIS (minor), Canada Yew.

$\begin{array}{rrrr}\text { Canada } & \text { Yew. } & & \\ 6-9 \text { in. } & 1.00 & 9.00 & 81.00 \\ 9-12 \text { in. } & 1.50 & 13.00 & 120.00 \\ 12-18 \text { in. } & 2.00 & 18.00 & \end{array}$

TAXUS CUSPIDATA, Japanese Yew.

\begin{tabular}{|c|c|c|c|}
\hline & Each & 10 & 100 \\
\hline $9-12$ in. & .30 & 2.00 & 18.00 \\
\hline $12-18$ in. & 1.00 & 9.00 & 81.00 \\
\hline $18-24$ in. & 1.50 & 13.50 & 120.00 \\
\hline $2-3 \mathrm{ft}$ & 2.00 & 18.00 & 162.00 \\
\hline $3-4 \mathrm{ft}$. & 3.00 & 27.00 & \\
\hline $4-5 \mathrm{ft}$. & 4.00 & 36.00 & \\
\hline $5-6 \mathrm{ft}$. & 5.00 & 45.00 & \\
\hline
\end{tabular}

12-18 in. $\quad 2.00 \quad 18.00$

100

$\begin{array}{rrr}9-12 \mathrm{in.} & 2.00 & 18.00 \\ 15-18 \mathrm{in} . & 3.00 & 27.00 \\ 18-24 \mathrm{in} & 4.00 & 36.00 \\ 2-21 / 2 \mathrm{ft} . & 5.00 & 45.00\end{array}$

TAXUS CUSPIDATA NANA (brevifolia), Dwarf Japanese Yew.

$\begin{array}{rrr}9-12 \text { in. } & 2.00 & 18.00 \\ 12-18 \text { in. } & 4.00 & 36.00\end{array}$

\section{THE ARBORVITAES, Thuja}

THUJA OCCIDENTALIS, American Arborvitae.

THUJA OCCIDENTALIS GLOBOSA, American Globe Arborvitae.

$12-18$ in. $\quad 1.50 \quad 13.50$

THUJA OCCIDENTALIS AUREA, Golden American Arborvitae.

THUJA OCCIDENTALIS WAREANA, Ware Arborvitae. $6.75 \quad 60.00$

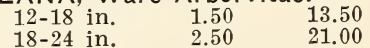


HORTICULTURAL VARIETIES OF THUJA.

AMERICAN PYRAMIDAL ARBORVITAE (occidentalis pyramidalis).

\begin{tabular}{rrrr}
$6-9$ in. & Each & 10 & \multicolumn{1}{c}{100} \\
$9-12$ in. & 1.00 & 6.75 & 60.00 \\
$12-18$ in. & 1.50 & 9.00 & 81.00 \\
$18-24$ in. & 2.00 & 13.50 & 120.00 \\
$2-3$ ft. & 3.25 & 30.00 & 162.00 \\
& & &
\end{tabular}

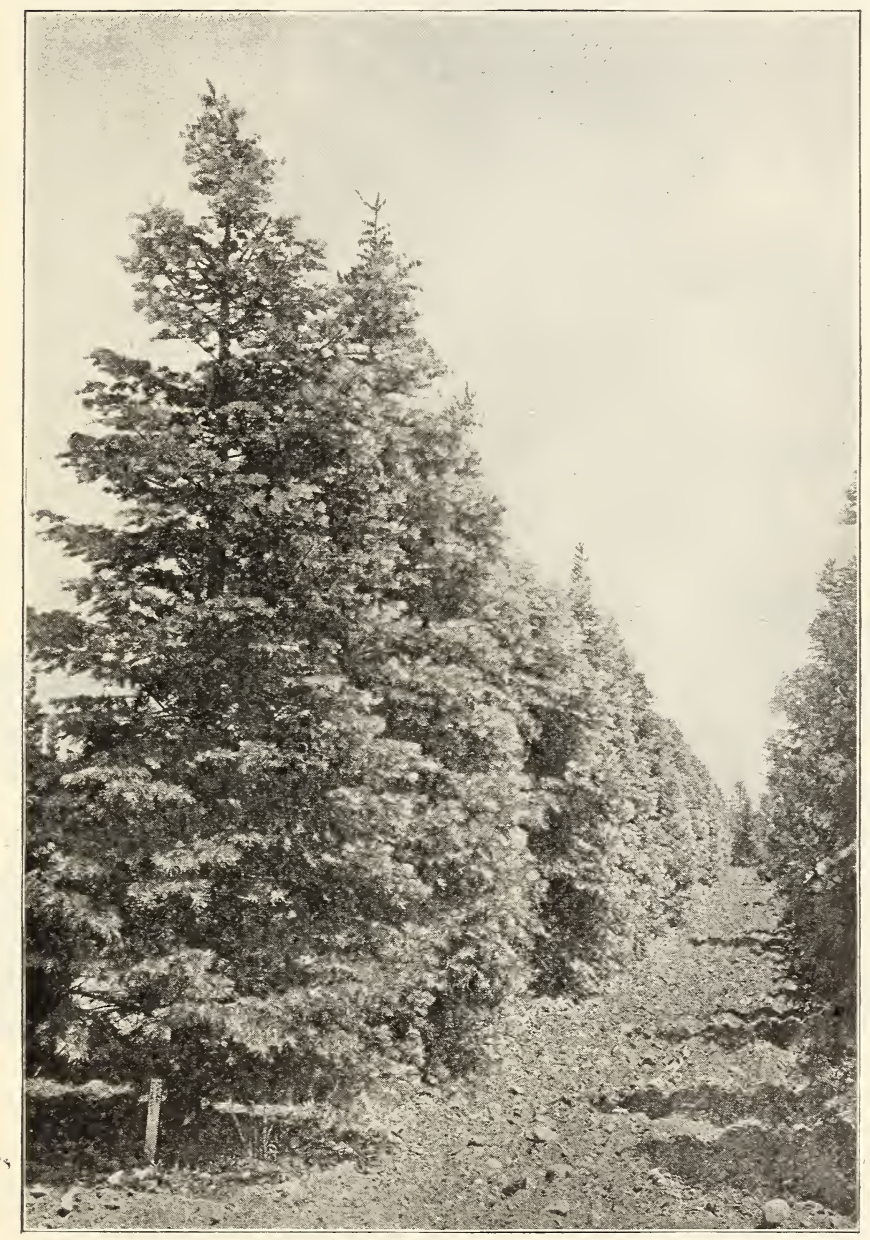

ABIES CONCOLOR, White Fir.

Large specimens at Boxford-Highlands Nursery. 


\section{KELSEY'S HARDY AMERICAN PLANTS}

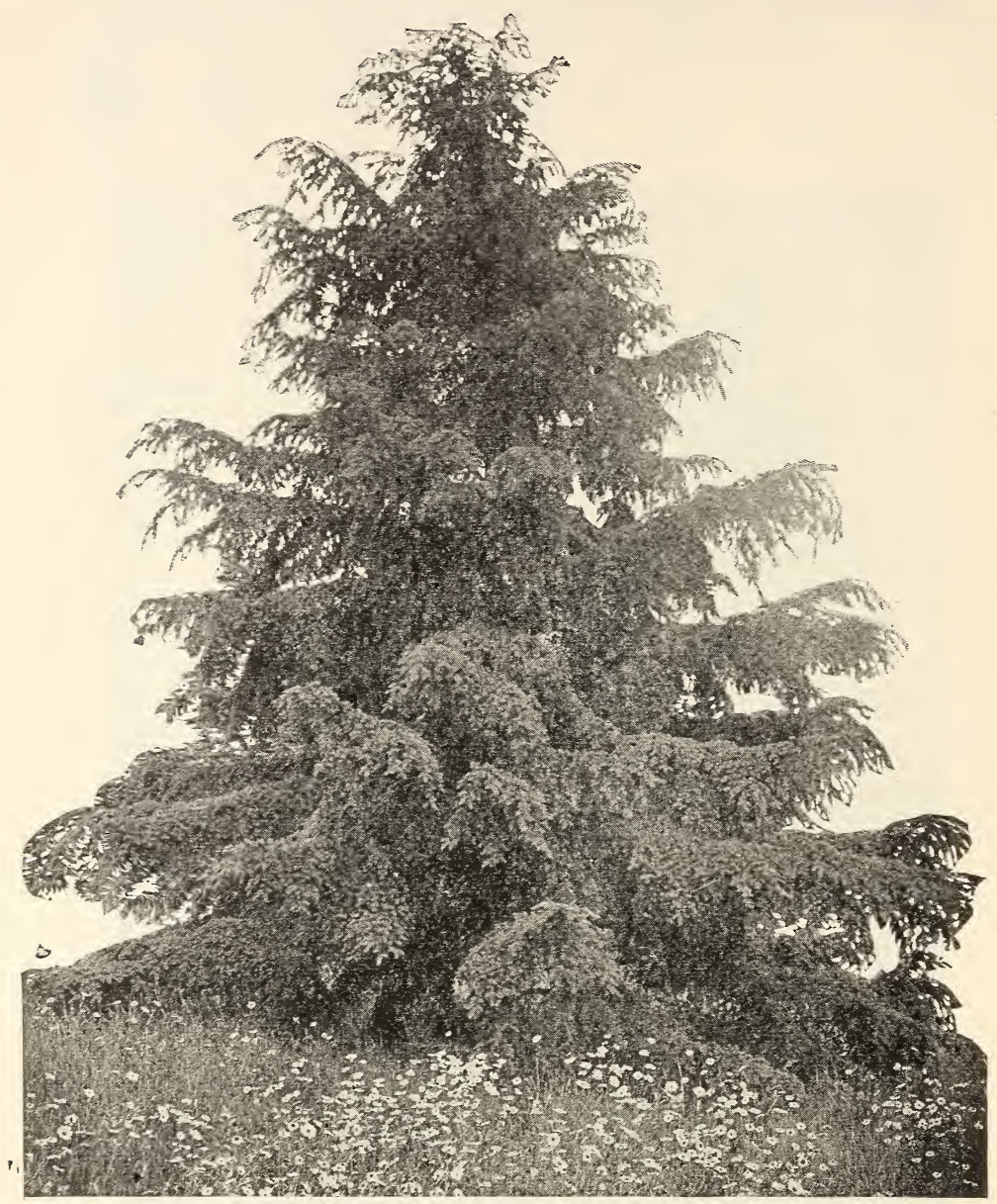

\section{CAROLINA HEMLOCK (Tsuga caroliniana)}

"Its dense, dark foliage, sweeping semi-pendulous branches, and eventually pyramidal form, combine to give a charm not found in any other evergreen known to cultivation."

Photographed by Harlan P. Kelsey at the Arnold Arboretum, Jamaica Plain, Mass. 


\section{THE HEMLOCKS, Tsuga}

TSUGA CANADENSIS, Canada Hemlock.

Sizes from $6 \mathrm{ft}$. up are extra heavy specimens.

$\begin{array}{rrrr} & \text { Each } & 10 & 100 \\ 6-9 \text { in. } & .50 & 4.50 & 39.00 \\ 9-12 \text { in. } & .75 & 6.75 & 60.00 \\ 12-18 \text { in. } & 1.00 & 9.00 & 81.00 \\ 18-24 \text { in. } & 1.75 & 16.00 & \\ 2-3 \text { ft. } & 2.50 & 24.00 & 200.00 \\ 5-6 \mathrm{ft} . & 7.00 & 63.00 & \\ 6-7 \mathrm{ft} . & 10.00 & 90.00 & \\ 7-8 \mathrm{ft} . & 15.00 & 135.00 & \\ 8-10 \mathrm{ft} . & 18.00 & 156.00 & \\ 10-12 \mathrm{ft} . & 25.00 & 225.00 & \\ 12-14 \mathrm{ft} . & 30.00 & 270.00 & \end{array}$

TSUGA CANADENSIS PENDULA, Sargent Weeping Hemlock. $2-21 / 4$ ft. sprea.d, $\$ 15.00$.

TSUGA CAROLINIANA, Carolina Hemlock.

Carolina Hemlock is unique in habit, with dark, dense, tufted foliage on sweeping pendulous branches with a "Japanese effect."

It is hardier and more adapted to trying city atmospheres than the Canada Hemlock and seems to thrive in southern latitudes where the latter becomes thin, yellow and unsightly. Professor C. S. Sargent, Director of the Arnold Arboretum, says, in a letter dated October 30, 1923: "As you know I consider this tree (Carolina Hemlock) the handsomest conifer we can grow in New England."

$\begin{array}{rrrr}12-18 \text { in. } & 1.50 & 14.00 & 132.00 \\ 18-24 \text { in. } & 2.25 & 20.00 & 180.00 \\ 2-3 \text { ft. } & 3.50 & 30.00 & 270.00 \\ 3-4 \text { ft. } & 6.00 & 50.00 & 450.00 \\ 4-5 \text { ft. } & 12.00 & 100.00 & \\ 5-6 \text { ft. } & 20.00 & 180.00 & \\ 6-7 \mathrm{ft} . & 30.00 & 270.00 & \\ 7-8 \mathrm{ft} . & 40.00 & 360.00 & \end{array}$

\section{RHODODENDRONS, KALMIAS AND OTHER HARDY BROADLEAF EVERGREENS}

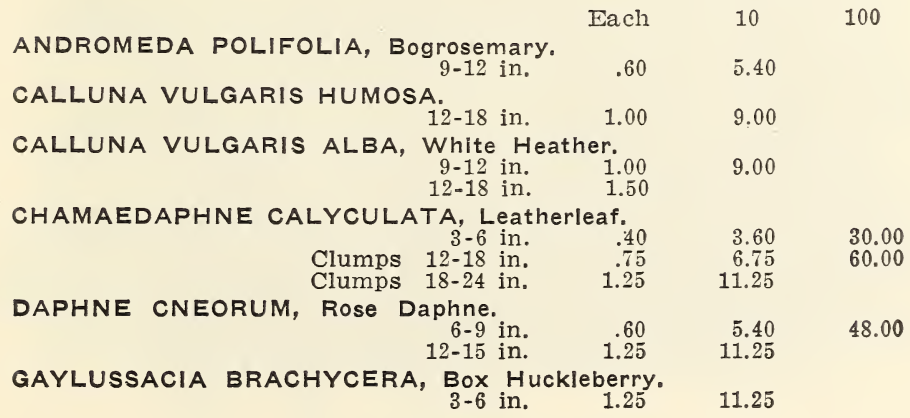




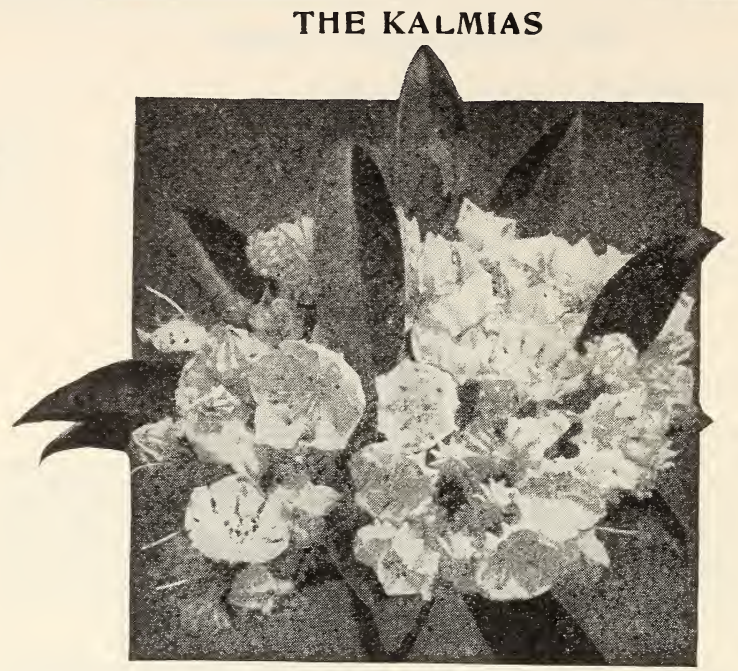

Kalmia latifolia, detall of flowers

KALMIA AUGUSTIFOLIA, Lambkill.

A dwarf species, making a fine ground cover.

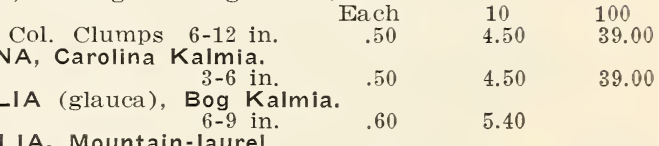

KALMIA LATIFOLIA, Mountain-laurel.

One of the most beautiful of our broadleaf Evergreen Shrubs, of

surpassing beauty when in bloom. Boxford-Highlands Nursery

has thousands of flowering-size clumps.

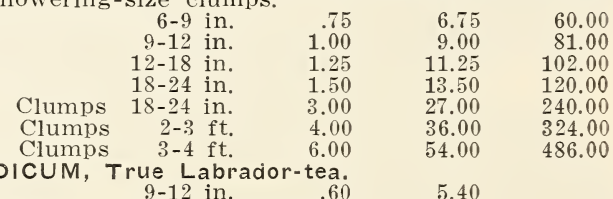

LEDUM GROENLANDICUM, True Labrador-tea. $9-12$ in. $\quad .60$

LEIOPHYLLUM BUXIFOLIUM, BOX Sandmyrtle.

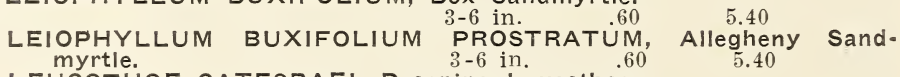

LEUCOTHOE CATESBAEI, Drooping Leucothoe.

Invaluable as a border or undershrub and for edging the Rhododendron and Azalea plantation. The "spray" foliage turns a rich

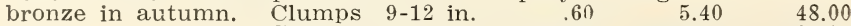

Clumps $12-18$ in. $\quad 1.00 \quad 9.00 \quad 81.00$

Clumps $18-24$ in. $\quad 1.50 \quad 13.50 \quad 120.00$

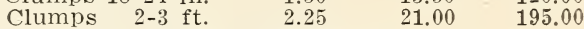

PACHYSANDRA TERMINALIS, Japanese Pachysandra.

PIERIS (Andromeda) FLORIBUNDA, Mountain Andromeda $1.75 \quad 15.00$

PIERIS (Andromeda) FLORIBUNDA, Mountain Andromeda. 102.00

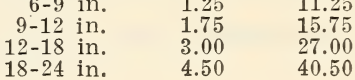




\section{RHODODENDRONS}

The Native American Rhododendrons are the best for American planting, being hardier than both the "hybrids" and the many Asiatic species. Even where the hardier of the hybrid varieties are successful, the dark-foliaged American species maximum and catawbiense should form the main background.

RHODODENDRON CAROLINIANUM, Carolina Rhododendron.

A clear pink American species, introduced by Harlan P. Kelsey many years ago. There is no magenta shade in the flowers. Entirely hardy and fine for massing on hillsides and in rockeries.

$\begin{array}{lrrrr} & & \text { Each } & 10 & 100 \\ & 9-12 \text { in. } & 1.00 & 9.00 & 81.00 \\ 12-18 \text { in. } & 1.50 & 13.50 & \\ \text { Clumps } & 12-18 \text { in. } & 2.50 & 21.00 & \\ \text { Clumps } 18-24 \text { in. } & 4.00 & 36.00 & \end{array}$

RHODODENDRON CAROLINIANUM ALBUM, White Carolina Rhododendron. A white natural variety of the above, also an introduction of Mr. Kelsey's.
Collected seedlings
6-9 in.
1.00
9.00

RHODODENDRON CATAWBIENSE, Catawba Rhododendron.

The hardiest and best all-round Rhododendron and the one which supplied color and hardiness to the cultivated hybrids. Color, bright red-purple. Leaves dark shiny green.

$\begin{array}{rrrrr}\text { Leaves dark shiny } & \text { green. } & & \\ & 3-6 \text { in. } & .60 & 5.40 & 48.00 \\ 6-9 \text { in. } & 1.00 & 9.00 & 81.00 \\ 9-12 \mathrm{in.} & 1.25 & 11.25 & 102.00 \\ 12-18 \mathrm{in} . & 1.75 & 15.75 & 141.00 \\ & 18-24 \mathrm{in} . & 2.40 & 21.00 & 195.00 \\ \text { Clumps } & 12-18 \mathrm{in} . & 2.40 & 21.00 & 195.00 \\ \text { Clumps } & 2-3 \mathrm{ft} . & 4.00 & 36.00 & \\ \text { Clumps } & 3-4 \mathrm{ft} . & 6.00 & 54.00 & \\ \text { Clumps } & 4-5 \mathrm{ft} . & 9.00 & 81.00 & \end{array}$

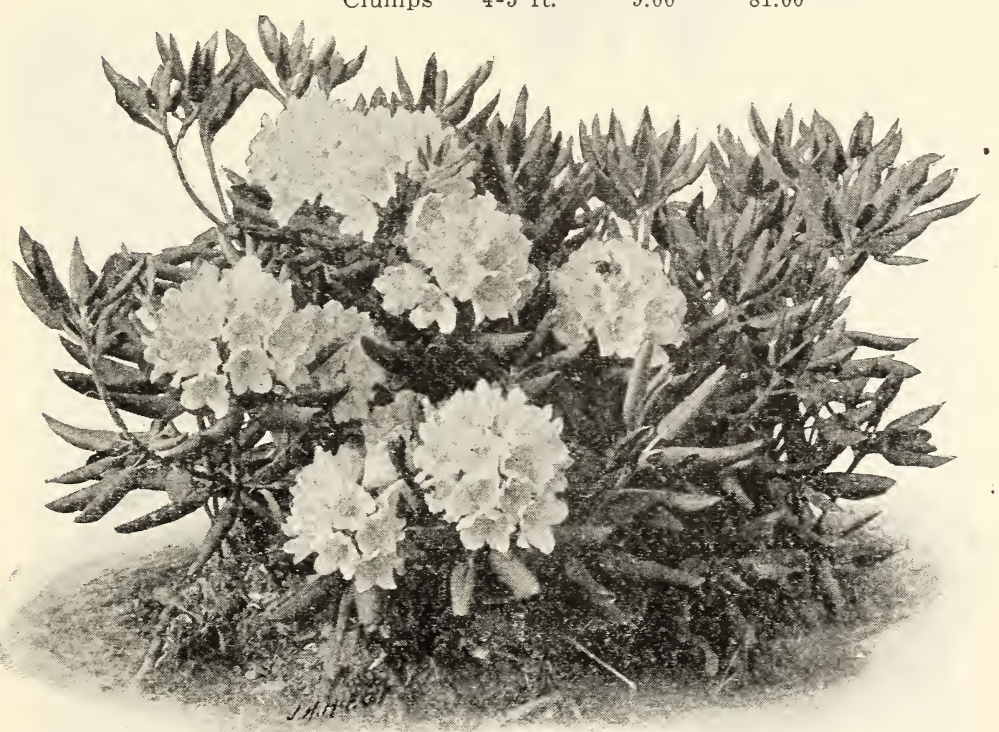


KELSEY'S HARDY AMERICAN PLANTS

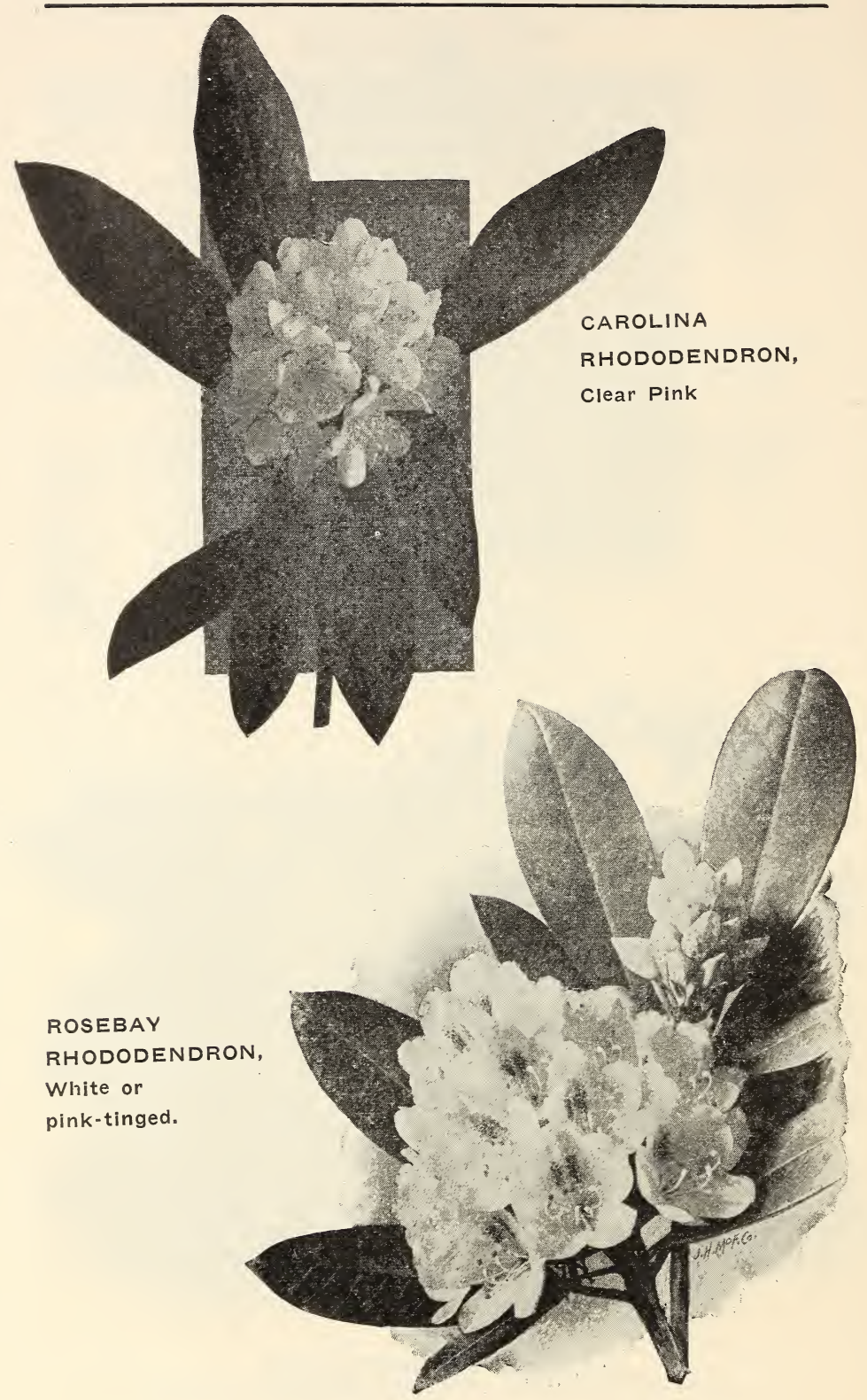


RHODODENDRON CATAWBIENSE COMPACTA.

$A$ dense growing variety discovered and introduced by Harlan $P$.

Kelsey. Very distinct from the catawbiense type.

$\begin{array}{lrrrr} & & \text { Each } & 10 & 100 \\ \text { Clumps } & 9-12 \text { in. } & 2.50 & 21.00 & 195.00 \\ \text { Clumps } & 12-18 \text { in. } & 3.00 & 27.00 & 240.00 \\ \text { Clumps } & 18-24 \text { in. } & 4.00 & 36.00 & 324.00 \\ \text { Clumps } & 2-3 \text { ft. } & 6.00 & 54.00 & \end{array}$

RHODODENDRON MAXIMUM, Rosebay Rhododendron.

The white or pink-tinged flowers and late-blooming habit make this species invaluable for hardy Rhododendron plantings.

RHODODENDRON MINUS, Piedmont Rhododendron.

$$
\text { 9-12 in. } 1.25 \quad 11.25
$$

RHODODENDRON MUCRONULATUM, Korean Rhododendron.

A. hardy Asiatic species. $3-6$ in. $\quad .75$. 6.75600

HORTICULTURAL VARIETIES OF RHODODENDRONS.

Some of the hardiest sorts as named below.

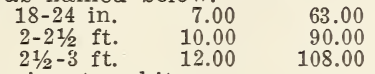

Album Elegans, blush, changing to white.

Caractacus, purplish crimson.

Charles Dickens, dark scarlet.

Ignatius Sargent, deep pink.

Mrs. Milner, rich crimson.

Opal (Luteoroseum), rose, blotched yellow.

Parsons Grandiflorum, rose.

Purpureum Elegans, royal-purple.

Roseum Elegans, rose.

Myrtle, Myrtifolium, deep rosy-pink.

$12-18$ in.

$18-24$ in.

Wilson (laetivirens). $\quad \begin{array}{rr}21 / 2-3 \\ \mathrm{ft} .\end{array} \quad 12.00$

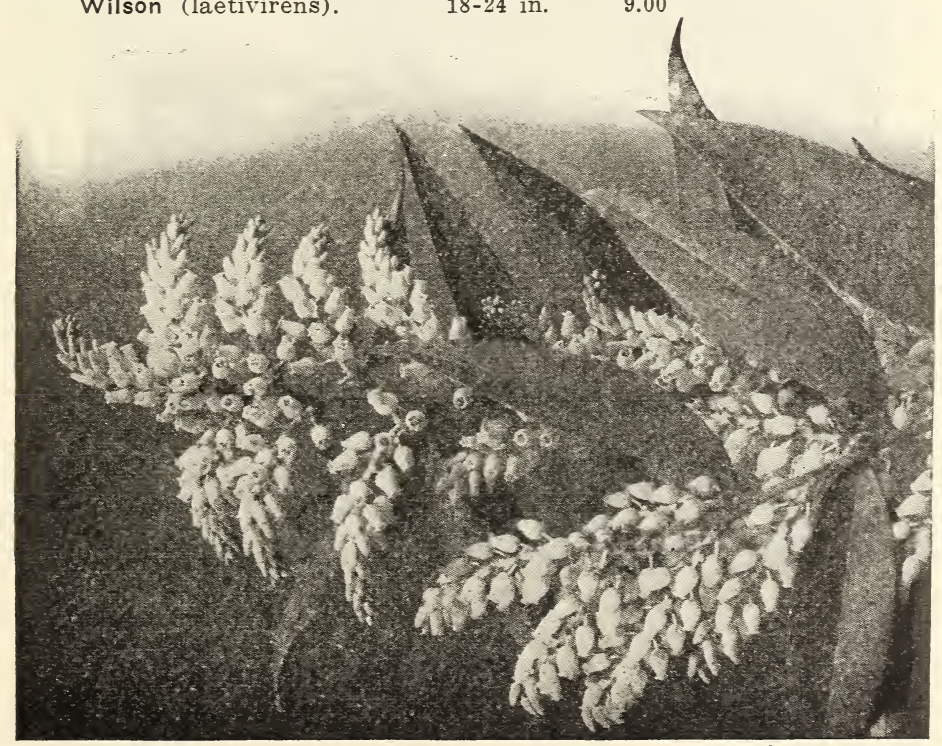

DROOPING LEUCOTHOE (L. catesbael)

The most beautiful broadleaf evergreen for low borders in America 


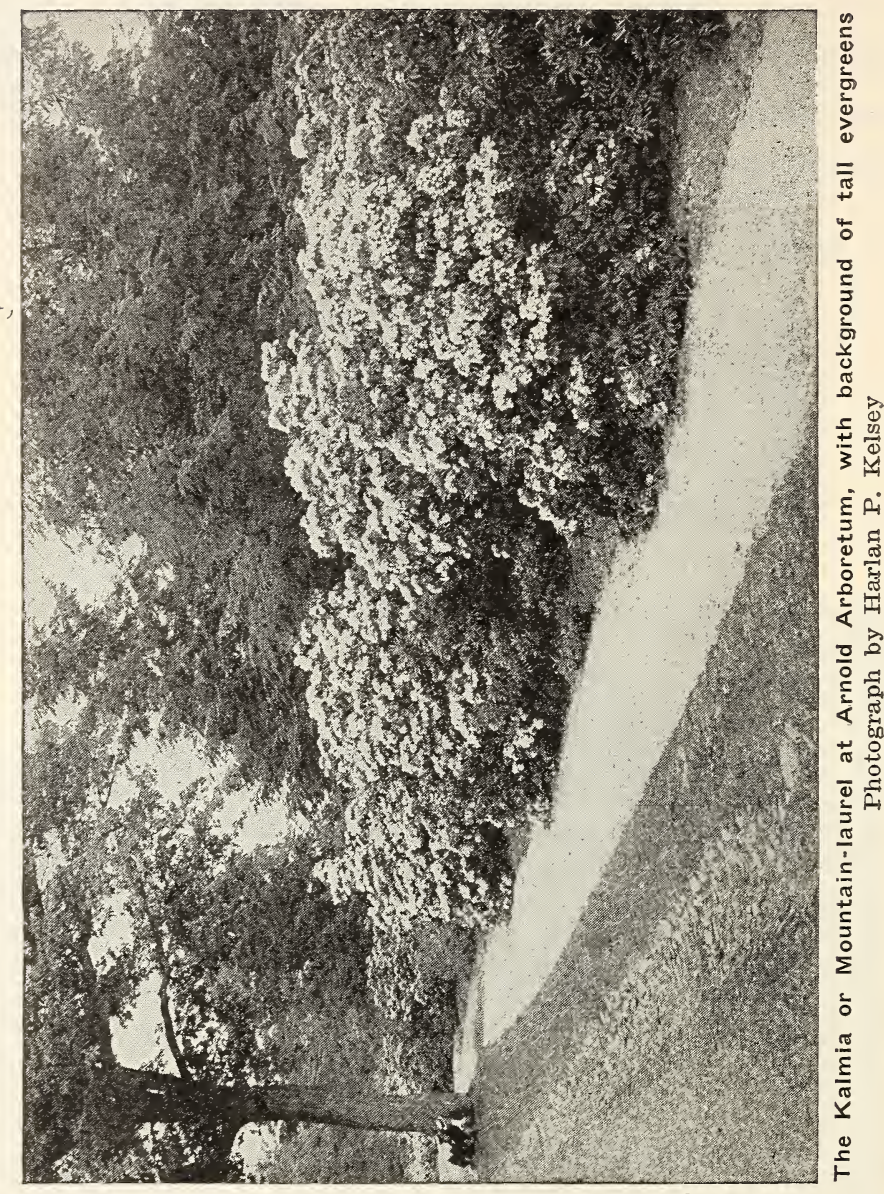




\section{DECIDUOUS TREES AND SHRUBS}

ACER BUERGERIANUM, TrIdent Maple. Each

$12-18$ in. $\quad .60$
$18-24$ in. $\quad 1.00$

ACER DASYCARPUM (saccharinum), Silver Maple.

$9.00 \quad 81.00$ $3-4$ in. caliper $16-18 \mathrm{ft}$. $\quad 15.00$ ACER GINNALA, Amur Maple.

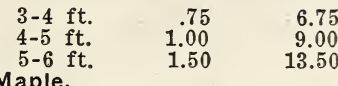

ACER PLATANOIDES, Norway Maple.

$\begin{array}{rr}12-18 \mathrm{in} . & .30 \\ 18-24 \mathrm{in} . & .50 \\ 6-8 \mathrm{ft} & 1.50 \\ 8-10 \mathrm{ft} & 3.00 \\ 10-12 \mathrm{ft} & 4.50 \\ 12-14 \mathrm{ft} & 6.00 \\ 14-16 \mathrm{ft} & 8.00 \\ 16-20 \mathrm{ft} & 12.00\end{array}$

2.70

4.50

21.00

13.50

27.00

39.00

40.50

54.00

Extra caliper at special prices.

ACER RUBRUM, Red Maple.

ACER SACCHARUM, Sugar Maple.

$\begin{array}{ll}2-3 \mathrm{ft} . & .30 \\ 3-4 \mathrm{ft} . & .50 \\ 4-5 \mathrm{ft} . & .75 \\ 6-8 \mathrm{ft} . & 2.00\end{array}$

2.40
4.50
6.75

18.00

$$
\begin{array}{r}
2-3 \mathrm{ft} . \\
3-4 \mathrm{ft} . \\
4-6 \mathrm{ft} . \\
6-8 \mathrm{ft} . \\
8-10 \mathrm{ft} .
\end{array}
$$

ACER SPICATUM, Mountain Maple.

$$
\text { Seedlings } 2-3 \mathrm{ft} \text {. } \quad .40 \quad 3.00
$$

$\begin{array}{rr}3.00 & 27.00 \\ 4.50 & 39.00 \\ 6.75 & 60.00 \\ 11.25 & 102.00 \\ 18.00 & 162.00\end{array}$

21.00

27.00

HORTICULTURAL VARIETIES OF ACER.

Wier Maple (Acer saccharinum wieri).

$$
\begin{array}{rrr}
4-5 \mathrm{ft} . & 1.00 & 9.00 \\
10-12 \mathrm{ft} . & 3.00 & 27.00 \\
12-14 \mathrm{ft} . & 4.00 & 36.00
\end{array}
$$

Pyramidal Sllver Maple (Acer dasycarpum pyramidale). 5-6 ft. $\quad 3.50 \quad 31.50$

$$
2-21 / 2 \text { in. caliper } \quad 6.00 \quad 54.00
$$

AMELANCHIER ALNIFOLIA, SASKATOON. $10-15$ in. $.30 \quad 2.70$

AMELANCHIER CANADENSIS, Downy Shadblow.

AMORPHA TENNESSEENSIS, Tennessee-indigo. $\quad 5.40$

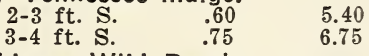

AMYGDALUS DAVIDIANA, Chlnese Wild Peach.

ARALIA SPINOSA, Devils-Walkingstick. $\quad 30 \quad 2.40$

ARONIA ARBUTIFOLIA, Red Chokeberry. $\begin{array}{cccc}6-12 \text { in. } & .30 & 2.70 & 24.00\end{array}$

$\begin{array}{cccc}6-12 \text { in. } & .30 & 2.70 & 24.00 \\ 1-2 \mathrm{ft} & .60 & 5.40 & 48.00 \\ 2-3 \mathrm{ft} & .75 & 6.75 & \end{array}$

ARONIA MELANOCARPA, Black Chokeberry.

$$
\begin{aligned}
& \text { 9-12 in. } \quad 30 \quad 2.70 \\
& \text { 18-24 in. } \quad .40 \quad 3.60 \\
& \begin{array}{lrrr}
\text { Clumps } & 2-3 \mathrm{ft} . & .60 & 5.40 \\
\text { Clumps } & 3-4 \mathrm{ft} . & 1.00 & 9.00
\end{array}
\end{aligned}
$$

21.00

ARONIA MELANOCARPA GRANDIFOLIA, Great Black Chokeberry.

$$
\begin{array}{lll}
3-4 \mathrm{ft} \text {. } & 1.00 & 9.00
\end{array}
$$


KELSEY'S HARDY AMERICAN PLANTS

\section{THE BEST HARDY AMERICAN AZALEAS}

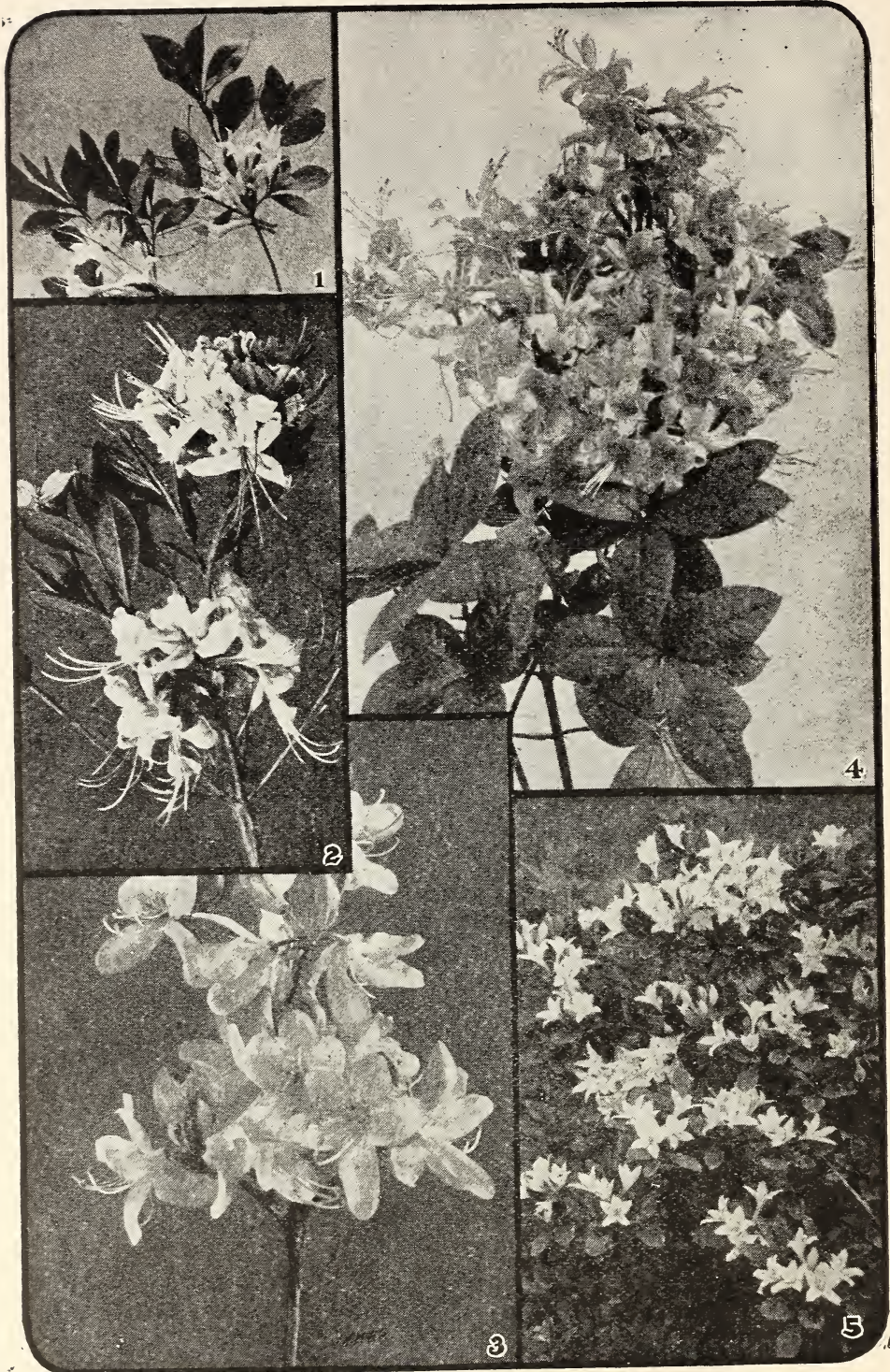

1. Azalea viscosa 4. Azalea calendulacea
2. Azalea

udiflora

5. Azalea arborescens 


\section{HARDY AMERICAN AZALEAS}

The American Azaleas are among the choicest of all ornamentals, whether exotic or native, and were but rarely seen in cultivation before being disseminated by Boxford-Highlands Nursery.

They are seen at their best when planted in large masses, and in properly prepared beds they richly repay any unusual care given them. Like most ericaceous plants, they love deep, moist, well-drained soil, and these showy native species are particularly adapted to planting in shrub borders and with Rhododendrons, their brilliant blossoms being set off by a background of dark foliage. Azaleas can be successfully grown almost anywhere, following the same instructions given for Rhododendrons. The complete hardiness of all the species we offer is unquestionable. No American shrubs equal the native Azaleas, particularly Azalea calendulacea, for woodland and hillside plantings.

Our cold Carolina mountains have added no more beautiful plants to the garden than these American Azaleas, not excepting the magnificent broad-leaf evergreen Rhododendrons of world-wide fame.

arborescens, Sweet Azalea. 5 to 15 feet. In June the delightfully spicy, fragrant white flowers, with pink stamens, appear in profusion, lasting for weeks. Becomes a spreading clump, 3 to 6 feet broad, in cultivation; easy culture. The foliage of this variety often colors striking shades of red in late autumn, and is the best of all genus. The clumps offered have from 25 to 100 stems and are heavily budded with enormous balls.

calendulacea, Flame Azalea. 6 to 15 feet. The most regal of all the species, native or exotic, and a noble representative of our rich Carolina mountain flora. Bartram, speaking of it in his "Travels," calls it the "fiery Azalea," and says: "This epithet "fiery' I annex to this most celebrated species of Azalea, as being expressive of the appearance of its flowers, which are in general of the color of the finest red lead, orange, and bright gold, as well as vellow and cream-color. This is certainly the most gay and brilliant-flowering' shrub yet known." No more striking landscape effect can be produced than a hillside of Azalea calendulacea in full bloom. Nearly all quoted above 18 inches are budded. These Azalea calendulacea are splendid clumps, with a mass of buds, and range in color from light sulphur-yellow to deep red.

nudiflora, Pinxter Flower. Beautiful clear pink, blooming very early, just following $A$. vaseyi.

vaseyi, Pinkshell Azalea. 6 to 15 feet. This showy Azalea was discovered only as late as 1878, and introduced by Highlands Nursery very soon after. It is of easy culture and is perhaps the most profuse bloomer of all the native species, and the more conspicuous as its white, pink, or deep rose-colored flowers appear in early April or May before the foliage. Of erect, slender habit naturally, in cultivation it becomes more spreading, while retaining the charming light stem-growth. Autumn usually turns the leaves a deep, dark crimson, greatly enhancing its beauty and value.

vicosa, Swamp Azalea. White, sometimes tinged with pink. Makes fine clumps, often reaching a height of 10 to 12 feet. Quite fragrant.

AZALEA ARBORESCENS, Sweet Azalea,

$\begin{array}{rrrr}3-6 \text { in. } & 1.00 & 8.40 & 75.00 \\ 12-18 \text { in. } & 1.50 & 13.50 & 120.00 \\ 18-24 \text { in. } & 2.00 & 18.00 & 162.00 \\ 2-3 \text { ft. } & 3.00 & 27.00 & 240.00 \\ 18-24 \text { in. } & 3.00 & 27.00 & 240.00 \\ 2-3 \text { ft. } & 4.50 & 40.50 & \\ 3-4 \text { ft. } & 7.00 & 63.00 & \end{array}$

AZALEA CALENDULACEA (lutea), Flame Azalea.

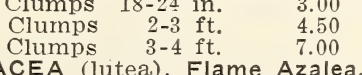

zalea.

$18-24$ in. $\quad 1.50$

$2-3 \mathrm{ft}$. 2.00

2.00
3.00

$2-3 \mathrm{ft}$.

Clumps

$3-4 \mathrm{ft}$

AZALEA KAEMPFERI, Torch Azalea.

8-10 in.

5.00

9.00

81.00

$13.50 \quad 120.00$

18.00

27.00

45.00

AZALEA VASEYI, Pinkshell Azalea.

9-12 in.

12-18 in.

1.00

9.00

162.00

18-24 in.

1.00

1.25

9.00

2.40

11.25

2-3 ft.

3.50 
AZALEA VIscosA, Swamp Azalea.

$\begin{array}{rr}12-18 \text { in. } & \text { Each } \\ 18-24 \text { in. } & .60 \\ 18-24 \text { in. } & 1.00 \\ 2-3 \text { ft. } & 2.75 \\ 3-4 \text { ft. } & 3.50 \\ 4-5 \text { ft. } & 6.00\end{array}$

10

5.40

9.00

15.75

22.50

31.50

\section{Clumps}

Clumps

4-5 $\mathrm{ft}$.

18-24 in.

BERBERIS KOREANA, Korean Barberry.

1.00

54.00

9.00

1.00

9.00

BERBERIS POIRETI, Poiret Barberry.

Seedlings $9-12$ in.

.40

3.60

BERBERIS SIEBOLDI, Siebold Barberry. $21 / 2-3 \mathrm{ft}$. .60

BERBERIS THUNBERGI, Japanese Barberry. $12-18$ in.

BERBERIS THUNBERGI MAXIMOWICZI, cora

$$
12-18 \text { in. }
$$
18-24 in.

BERBERIS THUNBERGI MINOR, BOX

$$
\begin{array}{r}
6-9 \text { in. } \\
9-12 \text { in. }
\end{array}
$$

BERBERIS

$$
\text { Seedlings } 9-12 \text { in. }
$$

BERBERIS VULGARIS, European Barberry.

$$
\text { Seedlings } 9-12 \text { in. }
$$
18-24 in. $2-3 \mathrm{ft}$.

.60

$\begin{array}{ll}.40 & 3.60 \\ .60 & 5.40\end{array}$

$\begin{array}{rr}.40 & 3.60 \\ .60 & 5.40\end{array}$

5.40

6.75

.60
.75
.50

4.50

6.75

3.60

2.10

2.40

3.60

100

48.00

81.00

141.00

201.00

.40

BETULA ALBA, European White Birch.

$$
\begin{aligned}
& \text { Birch. } \\
& 2-3 \mathrm{ft} \text {. } \\
& 3-4 \mathrm{ft}
\end{aligned}
$$

$\begin{array}{rl}3-4 & \mathrm{ft} . \\ 10-12 & \mathrm{ft} .\end{array}$

BETULA LENTA, Sweet Birch.

$$
\text { 10-12 ft. }
$$

BETULA LUTEA, Yellow Birch.

$$
\text { 2-3 } \mathrm{ft} \text {. }
$$

BETULA NIGRA, River Birch.

$$
\text { 18-24 in. }
$$

.40

.50

BETULA PAPYRIFERA (papyracea), Canoe Birch.

BETULA POPULIFOLIA, Gray Birch.

$$
\text { Seedlings } 2-3 \mathrm{ft} \text {. } \quad .25
$$

2.10

18.00

CALLICARPA JAPONICA, Japanese Beautyberry.

2.40

21.00

CALYCANTHUS FLORIDUS, Common Sweetshrub. Clumps $12-18$ in.

CARPINUS CAROLINIANA (americana), American Hornbeam.

$$
\begin{aligned}
& \text { 4-5 ft. } \\
& \text { 5- } 6 \mathrm{ft} \text {. } \\
& \text { 6-8 } \mathrm{ft} \text {. } \\
& \text { 12-18 in. }
\end{aligned}
$$

CASTANEA PUMILA, Chinquapin.

CEPHALANTHUS OCCIDENTALIS, Common Buttonbush.

CHIONANTHUS VIRGINICA, White Fringetree.

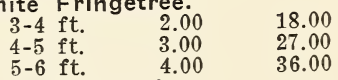

CLADRASTIS (Virgilia) LUTEA, Yellow-wood.

$$
\begin{array}{rr}
5-6 \mathrm{ft} & .75 \\
6-8 \mathrm{ft} & 1.00 \\
8-10 \mathrm{ft} & 1.50
\end{array}
$$

CLETHRA ACUMINATA, Cinnamon Clethra. 
CLETHRA ALNIFOLIA, Summersweet. Each 10

$\begin{array}{lrl} & & \\ 12-18 \text { in. } & \text { Each } & 10 \\ 18-24 \text { in. } & .50 & 4.50 \\ 18-24 \text { in. } & 1.00 & 5.40 \\ & & 9.00\end{array}$

Clumps,18-24 in. $\quad 1.00 \quad 9.00$

$\begin{array}{ccc}\text { CLETHRA TOMENTOSA, Woolly Clethra. } & \\ 18-24 \mathrm{in} . & .75 & 6.75\end{array}$

CORNUS ALBA, Tatarian Dogwood.

12-15 in. $\quad .30 \quad 2.70$

100

.50

$2.70 \quad 21.00$

CORNUS ALBA SIBIRICA, Coral Dogwood.

$2-3 \mathrm{ft} . \quad .60$

5.40

CORNUS ALBA ALTERNIFOLIA, Pagoda Dogwood. CORNUS BRETSCHNEIDERI.

$$
\text { Seedlings } 12-18 \text { in. } \quad .40 \quad 3.60
$$

$$
\text { Seedlings } \quad 6-9 \text { in. } \quad .30 \quad 2.40
$$

CORNUS FLORIDA, FlowerIng Dogwood.

$$
2-3 \mathrm{ft} \text {. } \quad .60
$$

CORNUS FLORIDA RUBRA, Redflowering Dogwood.

$$
\begin{array}{lrr}
2-3 \mathrm{ft} & 1.25 & 11.25 \\
3-4 \mathrm{ft} & 2.00 & 18.00 \\
4-5 \mathrm{ft} & 3.50 & 31.50 \\
5-6 \mathrm{ft} & 5.00 & 45.00 \\
6-7 \mathrm{ft} & 7.00 & 63.00 \\
7-8 \mathrm{ft} . & 10.00 & 90.00
\end{array}
$$

CORNUS PANICULATA (racemosa), Gray Dogwood.

$$
1-2 \mathrm{ft} . \quad .30 \quad 2.40
$$

CORNUS RUGOSA, Roundleaf Dogwood.

$$
\text { 18-24 in. } \quad .40 \quad 3.60
$$

$2-3 \mathrm{ft} . \quad .60 \quad 5.40$

CORNuS STOLONIFERA FLAVIRAMEA, Goldentwig Dogwood.

$\begin{array}{ccc}18-24 \text { in. } & .40 & 3.60 \\ 2-3 \mathrm{ft} . & .60 & 5.40\end{array}$

CORYLUS ROSTRATA, Beaked Hazelnut.

$\begin{array}{llll}\text { Hazelnut. } & & & \\ 2-3 \mathrm{ft} . & .50 & 4.50 & 39.00 \\ 3-4 \mathrm{ft} & .75 & 6.75 & \end{array}$

COTONEASTER ACUTIFOLIA VILLOSULA.

6-12 in. $1.00 \quad 9.00$

COTONEASTER AMBIGUA.

$$
\text { 12-18 in. } \quad 1.00 \quad 9.00
$$

COTONEASTER DIELSIANA, Diels Cotoneaster

$$
\begin{aligned}
& \text { Seedlings } 9-12 \text { in. } \quad .30 \quad 2.40 \\
& 12-18 \text { in. } \quad .60 \quad 5.40
\end{aligned}
$$

COTONEASTER DIVARICATA, Spreading Cotoneaster.

$$
\text { Seedlings } 18-24 \text { in. } \quad .50 \quad 4.50
$$

COTONEASTER HORIZONTALIS PERPUSILLA.
POTS $3-6$ in. 1.00

COTONEASTER INTEGERRIMA, European Cotoneaster.

$$
\begin{aligned}
& \text { Pots } 3-6 \text { in. } \quad 1.00 \quad 9.00 \\
& 2-3 \mathrm{ft} . \quad 1.25 \quad 11.25
\end{aligned}
$$

COTONEASTER LUCIDA (sinensis)

$$
\begin{array}{rrr}
18-24 \mathrm{in} . & .60 & 5.40 \\
2-3 \mathrm{ft} . & .75 & 6.75
\end{array}
$$

COTONEASTER MOUPINENSIS, Mupin Cotoneaster.

$$
\text { Pots } 6-9 \text { in. } 1.00 \quad 9.00
$$

CRATAEGUS ARKANSANA, Arkansas Hawthorn.

Seedlings $12-18$ in. $\quad .40 \quad 3.60$

CRATAEGUS ARNOLDIANA, Arnold Hawthorn.

$$
\begin{array}{llll}
\text { Seedlings } & 18-24 \mathrm{in.} & .40 & 3.60 \\
& 12-18 \mathrm{in} . & .50 & 4.50 \\
& 18-24 \mathrm{in} . & .75 & 6.75
\end{array}
$$

CRATAEGUS COCCINEA, Thicket Hawthorn.

Seedlings $\quad 9-12$ in. $\quad .25 \quad 2.10$

Seedlings 18-24 in. $\quad .40 \quad 3.60$

$\begin{array}{rr}18.00 \\ .60 & 30.00\end{array}$

CRATAEGUS CORDATA, Washington Hawthorn.

$\begin{array}{ccc}\text { Seedlings } & 12-18 \text { in. } & .40 \\ \text { CRATAEGUS MONOGYNA ALBOPLENA, Double English Hawthorn. } \\ 3-4 \mathrm{ft} . & 1.75 & 15.75\end{array}$ 
CRATAEgUS MONOGYNA PUNICEA, Single Pink Hawthorn.

$$
\begin{array}{ccc}
3-4 \mathrm{ft} . & \text { Each } & 10 \\
1.75 & 15.75
\end{array}
$$

100

CRATAEGUS NITIDA, Glossy Hawthorn.

$\begin{array}{lrrr}\text { awthorn. } & & & \\ 1-2 \mathrm{ft} . & .60 & 5.40 & 48.00 \\ 2-3 \mathrm{ft} . & .75 & 6.75 & 60.00 \\ 3-4 \mathrm{ft} . & 1.00 & 9.00 & \\ 4-5 \mathrm{ft} . & 1.50 & 13.50 & \end{array}$

CRATAEGUS OXYACANTHA SPLENDENS, Paul Double
Hawthorn.
H-4 ft. CRATAEGUS PRUNIFOLIA, PIUmleaf Hawthorn.

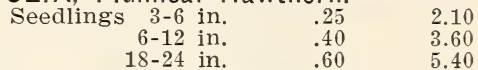

$2.10 \quad 18.00$

$\begin{array}{ll}3.40 & 48.00\end{array}$

CRATAEGUS PRUINOSA, Frosted Hawthorn. Seedlings 18-24 in.

CRATAEGUS PUNCTATA, Dotted Hawthorn.

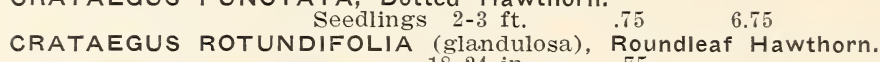

$6.75 \quad 60.00$

CRATAEGUS TOMENTOSA, Pear Hawthorn.

$$
\text { Seedlings 9-12 in. } .30
$$

HORTICULTURAL VARIETY OF CRATAEGUS.
Double Pink
3 - $4 \mathrm{ft}$.
1.75
15.75

CYDONIA JAPONICA, Flowering Quince.

DEUTZIA GRACILIS, Slender Deutzia.

$.30 \quad 2.70$

21.00

$.30 \quad 2.70$

$.50 \quad 4.50$

21.00

DEUTZIA LEMOINEI, Lemoine Deutzia.

DEUTZIA SCABRA CRENATA, Crinkle Deutzia.

$2.70 \quad 21.00$

12-18 in. $\quad .30$

$2-3 \mathrm{ft}$.

.30

2.70

5.40

HORTICULTURAL VARIETY OF DEUTZIA SCABRA.

Pride of Rochester $\quad 12-18$ in. $\quad .30 \quad 2.70$

DIERVILLA RIVULARIS, Georgia Bush-honeysuckle.

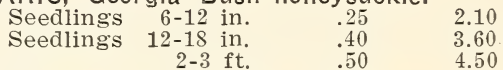

18.00

3.60
4.50

DIERVILLA SESSILIFOLIA, Southern Bush-honeysuckle.

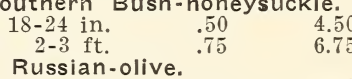

ELAEAGNUS ANGUSTIFOLIA, Russian-olive. 6-9 in. $\quad 25 \quad 2.10$

ENKIANTHUS CAMPANULATUS, Redvein Enkianthus. 9-12 in. 12-18 in. 18-24 in.

EUONYMUS ALATUS, Winged Euonymus.

$\begin{array}{lrr}\text { Euonymus. } & & \\ 9-12 \mathrm{in} . & .60 & 5.40 \\ 1-2 \mathrm{ft} . & .75 & 6.50 \\ 2-3 \mathrm{ft} . & 1.25 & 11.25 \\ 3-4 \mathrm{ft} . & 3.00 & 27.00 \\ 4-5 \mathrm{ft} . & 4.50 & 40.50\end{array}$

EUONYMUS BUNGEANUS, Winterberry Euonymus.

$\begin{array}{lrr}1-2 \mathrm{ft} & .75 & 6.50 \\ 2-3 \mathrm{ft} & 1.25 & 11.25 \\ 3-4 \mathrm{ft} . & 2.00 & 18.00\end{array}$

EUONYMUS EUROPAEUS, European Burnlngbush. $12-18$ in. $\quad .50 .4 .50$

18-24 in. $\quad .60 \quad 5.40$

EUONYMUS LATIFOLIUS, Broadleaf Burningbush.

$\begin{array}{rrrr}\text { Seedlings } & 9-12 \text { in. } & .25 & 2.10 \\ \text { Seedlings } & 18-24 \text { in. } & .40 & 3.60 \\ & 2-3 \mathrm{ft} . & 1.00 & 9.00 \\ & 3-4 \mathrm{ft} . & 1.60 & 14.40\end{array}$


EUONYMUS YEDOENSIS, Yeddo Euonymus. Each

10

$2-3 \mathrm{ft}$. $\quad 1.00$

9.00

FAGUS AMERICANA, American Beech.

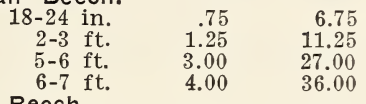

FAGUS SYLVATICA, European Beech.

$3-4$ ft. $2.50 \quad 22.50$

FAGUS SYLVATICA PURPUREA, Purple Beech.

$3-4 \mathrm{ft}$. 2.50

FAGUS SYLVATICA RIVERSI, Rivers Beech.

$$
4-5 \mathrm{ft} \text {. } \quad 3.50
$$

$6-7 \mathrm{ft}$. $\quad 5.00$

FORSYTHIA INTERMEDIA, Border Forsythia.

$\begin{array}{ll}12-18 \text { in. } & .25 \\ 18-24 & \text { in. }\end{array}$

Clumps $\quad 4-6 \mathrm{ft}$. $\quad 2.00$

FORSYTHIA SUSPENSA, Weeping Forsythia.

12-18 in. $\quad .25 \quad 2.10$

18-24 in. $\quad .30 \quad 2.70$

100

60.00

$\begin{array}{rrr}\text { FORSYTHIA SUSPENSA FORTUNEI, Fortune Forsythia. } \\ 12-18 \text { in. } & .30 & 2.70 \\ 18-24 \text { in. } & .50 & 4.50\end{array}$

$2.10 \quad 18.00$

$2.70 \quad 21.00$

18.00

18.00

21.00

21.00

FORSYTHIA SUSPENSA SIEBOLDI, Siebold Forsythia.

$$
\begin{array}{ccc}
12-18 \text { in. } & .30 & 2.70 \\
2-3 \mathrm{ft} . & .60 & 5.40
\end{array}
$$

21.00

FORSYTHIA VIRIDISSIMA, Greenstem Forsythia.

$$
\text { 12-18 in. } \quad .30 \quad 2.70
$$

GAYLUSSACIA BACCATA (resinosa), Black Huckleberry.

GENISTA TINCTORIA, Woadwaxen.

$$
\begin{array}{lll}
1-2 \mathrm{ft} & .40 & 3.60
\end{array}
$$

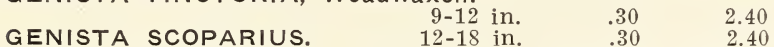

GYMNOCLADUS DIOICA (canandensis), Kentucky Coffeetree.

HALESIA MONTICOLA, Mountain Silverbell.

$\begin{array}{ccc}6-9 \text { in. } & .25 & 2.10\end{array}$

18.00

$\begin{array}{rrr}2-3 \mathrm{ft} . & 1.50 & 13.50 \\ 3-4 \mathrm{ft} . & 2.00 & 18.00 \\ 4-5 \mathrm{ft} . & 3.00 & 27.00 \\ 8-10 \mathrm{ft} & 8.00 & \end{array}$

HAMAMELIS VIRGINIANA, Common Witch-hazel.

$$
\begin{aligned}
& \text { Seedlings } 9-12 \mathrm{in} \quad .30 \quad 2.40 \\
& \begin{array}{lll}
12-18 \text { in. } \quad .40 & 3.60
\end{array}
\end{aligned}
$$

21.00

HIBISCUS SYRIACUS, Shrub-althea.

Named varieties, Reds and Whites, as follows: Amplissima, early red; Bicolor, double white with red markings; Boule de Feu, double red; Jeanne d'Arc, double pure white; Lady Stanley, double white. 6-12 in. .25

2.10

18.00

HYDRANGEA AREORESCENS, Smooth Hydrangea.

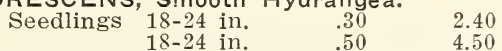

HYDRANGEA ARBORESCENS GRANDIFLORA, Snowhill Hydrangea. $\begin{array}{cccc}12-18 \text { in. } & .30 & 2.40 & 21.00 \\ 18-24 \text { in. } & .50 & 4.50 & \end{array}$

HYDRANGEA CINEREA, Ashy Hydrangea.

HYDRANGEA PANICULATA, Panicle Hydrangea. 12-18 in. 2.70

5.40

$2.70 \quad 24.00$

HYDRANGEA PANICULATA GRANDIFLORA, Peegee Hydrangea. $\begin{array}{rrrr}12-15 \text { in. } & .35 & 3.00 & 27.00 \\ 2-3 \mathrm{ft} . & .60 & 5.40 & \end{array}$

HYDRANGEA PANICULATA PRAECOX, Early Panicle Hydrangea.

HYDRANGEA PANICULATA TARDIVA, Late Panlcle Hydrangea.

HYDRANGEA QUERCIFOLIA, Oakleaf Hydrangea.

$3.00 \quad 27.00$ $12-18$ in. .60

HYPERICUM AUREUM, Golden St. Johnswort.

Seedlings 6-9 in. $\quad .25$

$2-3 \mathrm{ft} . \quad .50$

5.40

2.10

4.50

18.00 
HYPERICUM DENSIFLORUM.

$2-3 \mathrm{ft} . \quad$ Each

rubby St. Johnswort.

18-24 in. $2-3 \mathrm{ft}$.

.40

.60

ILEX MONTICOLA, Mountain Winterberry.

ILEX VERTICILLATA, Common Winterberry. Seedlings $\begin{array}{r}6-9 \\ 9-12\end{array}$ in. $12-18$ in. 18-24 in. $2-3 \mathrm{ft}$.

ITEA VIRGINICA, Sweetspire.

$$
\text { 12-18 in. } \quad 30
$$

KOELREUTERIA PANICULATA, Goldenrain-tree.

$8-15$ in.

LARIX

LARICINA (americana),

12-18 in. $\quad .30$

.25

\section{.25}

.30

.50

.75

LARIX EUROPAEA (decidua), European Larch.

$$
\begin{array}{lr}
3-4 \mathrm{ft} . & .60 \\
4-5 \mathrm{ft} & 1.00
\end{array}
$$

LARIX LEPTOLEPIS (kaempferi), Japanese Larch. $\begin{array}{ll}10-12 \mathrm{ft} & 4.00 \\ 12-14 \mathrm{ft} & 6.00\end{array}$

LEUCOTHOE RACEMOSA, Sweetbells.

$$
12-18 \text { in. } .40
$$

10

3.60

100

3.60

5.40

5.40

2.10

2.40

3.60

4.50

6.75

18.00

21.00

30.00

39.00

2.40

3.00

27.00

2.40

5.40

9.00

36.00

54.00

LEUCOTHOE RECURVA, Redtwig Leucothoe.

$$
18-24 \text { in. }
$$

1.00

3.60

5.40

9.00

LIGUSTRUM ACUMINATUM.

Seedlings 6-12 in.

LIGUSTRUM AMURENSE, Amur Privet (Northern

2.10

18.00

$.25 \quad 2.10$

\section{.}

LIGUSTRUM IBOTA, Ibota Privet.

$\begin{array}{lll}1-2 \mathrm{ft} . & .25 & 2.10\end{array}$

18.00

$$
\begin{array}{r}
6-12 \text { in. } \\
12-18 \text { in. }
\end{array}
$$

2-3 $\mathrm{ft}$.

.25

.30

1.50

2.70 $\begin{array}{ll}.50 & 4.50\end{array}$

12.00

21.00

LIGUSTRUM IBOTA REGELIANUM, Regel Privet. 2-3 $\mathrm{ft}$.

LIGUSTRUM VUlGARE, European Privet.

$.60 \quad 5.40$

39.00

$$
\begin{array}{r}
6-12 \\
15-24 \\
\text { in. }
\end{array}
$$
4-5 ft.

HORTICULTURAL VARIETY

.15

.20

1.40

1.80

IGUSTRUM.

48.00

Ibolium Privet (ibolium). $12-18$ in. $.25 \quad 2.10$

LONICERA FRAGRANTISSIMA, Winter Honeysuckle.

LONICERA MAACKI, Amur Honeysuckle.

$.25 \quad 2.10$

9.00

15.00

18.00

$2.10 \quad 18.00$

12 in. $\quad .50 \quad 4.50$

LONICERA MORROWI, Morrow Honeysuckle. $12-18$ in. 18-24 in.

.30

.40

2.70

3.60

24.00

30.00

LONICERA MUENDENIENSIS, Muenden Honeysuckle.

$$
\begin{array}{lrrr}
\text { Seedlings } & 12-18 \text { in. } & .30 & 2.40 \\
\text { Seedlings } & 2-3 \mathrm{ft} . & .40 & 3.60
\end{array}
$$

LONICERA TATARICA ALBA, White Tatarian Honeysuckle.

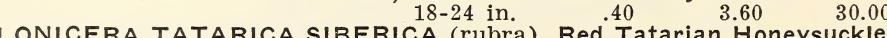

LONICERA TATARICA SIBERICA (rubra), Red Tatarian Honeysuckle. $18-24$ in. $\quad 40 \quad 3.60 \quad 30.00$

HORTICULTURAL VARIETY OF LONICERA.

White Belle Honeysuckle (bella albida).

$$
\begin{array}{ccc}
15-30 \mathrm{in.} & .25 & 1.80 \\
2-3 \mathrm{ft} . & .60 & 5.40
\end{array}
$$

LYONIA LIGUSTRINA, He-Huckleberry.

$$
\begin{aligned}
& 18-24 \mathrm{in} . \\
& 2-3 \mathrm{ft} .
\end{aligned}
$$

1.00

MAGNOLIA ACUMINATA, Cucumbertree. $12-18$ in. 


\section{THE FLOWERING CRABS}

The Flowering Crabs have few rivals among gorgeous Spring flowering trees and shrubs. At the Arnold Arboretum one of the important events of the year is the blooming of the Crabs, followed by the showy fruit.

They are of easy culture, and whether planted singly or in masses, give remarkable and quick results. Not only are the Flowering Crabs beautiful on the lawn, but they are used to the greatest advantage on a large scale in woodland and other mass plantings, as are Dogwoods and Hawthorns. No group of plants have greater value for enlivening open forest parks and the country roadside. They present striking effects when planted on parking strips of boulevards and wide city streets.

As soon as the ground can be worked is an ideal time for planting. Give rich soil and mulch heavily. Use all the water the soil will take in planting.

Description of species and varieties made up from Arnold Arboretum Bulletins.

\section{Prices of Flowering Crabs}

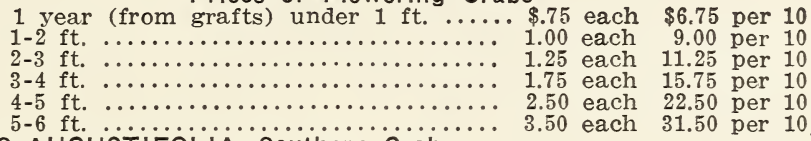

MALUS AUGUSTIFOLIA, Southern C̈rab.

Late blooming American species, bright pink and very fragrant. 1 year from grafts.

MALUS ARNOLDIANA, Arnold Crab.

One of the most beautiful varieties, originating at the Arnold Arboretum. Very large rose-colored flowers, turning to white. 1 year from grafts.

MALUS ATROSANGUINEA, Carmine Crab.

Much like floribunda, but with brilliant carmine flowers. 1 year from grafts, 2-3 ft., 3-4 ft., 4-5 ft.

MALUS BACCATA, Siberian Crab.

Tall, narrow tree, small white flowers and tiny orange or scarlet fruit. 1 year from grafts.

MALUS BACCATA MANDSHURICA, Manchurian Crab.

From China and Japan; its large pure white flowers quite fragrant; dark crimson fruit hangs on long stems. 1 year from grafts.

MALUS CORONARIA, Wild sweet Crab.

White and pink flowers, delightfully fragrant. Native American species. 1 year from gra.ft, $1-2 \mathrm{ft}$., $2-3 \mathrm{ft} ., 3-4 \mathrm{ft}$.

MALUS FLORIBUNDA, Japanese Flowering Crab.

One of the handsomest, bright pink flower buds, white flowers. Small yellowish fruit, much liked by birds. 1 year from grafts, 3-4 feet.

MALUS HALLIANA PARKMANI, Parkman Crab.

Bright rose-red, double flowers hang on long slender stems. A favorite in Japanese gardens. 1 year from grafts.

MALUS IOENSIS PLENA, Bechtel Crab.

Double pink flowers like small clustered roses. 1 year from grafts. 18-24 in., 2-3 ft.

MALUS MICROMALUS, Midget Crab.

Pale pink flowers from tiny deep rose-colored buds; small yellow fruit. Pyramidal habit. 1 year from grafts.

MALUS NIEDZWETZKYANA, Redvein Crab.

A Russian Turkestan species, remarkable for the red color of flowers, branches, leaves and fruit. 1 year from grafts, 2-3 ft., 3-4 ft., 4-5 ft., 5-6 ft.

MALUS PRUNIFOLIA, Pearleaf Crab.

Rare and perhaps the handsomest of the Asiatic Crabs, at least in fruit, which is $1 \frac{1}{2}$ in. long, very lustrus, bright red, or yellow with a red cheek. 4-5 ft., 5-6 ft.

MALUS PRUNIFOLIA RINKI (ringo), Chinese Apple.

Large white flowers, and red, yellow or green fruit, $1 \frac{1}{2}$ inches in diameter. Cultivated for its fruit in China. 1 year from grafts.

MALUS ROBUSTA, Cherry Crab.

Very early. Large white fragrant flowers and a handsome tree.

Dull red fruit, 1 inch in diameter. 1 year from grafts, 5-6 ft. 


\section{KELSEY'S HARDYAMERICAN PLANTS}

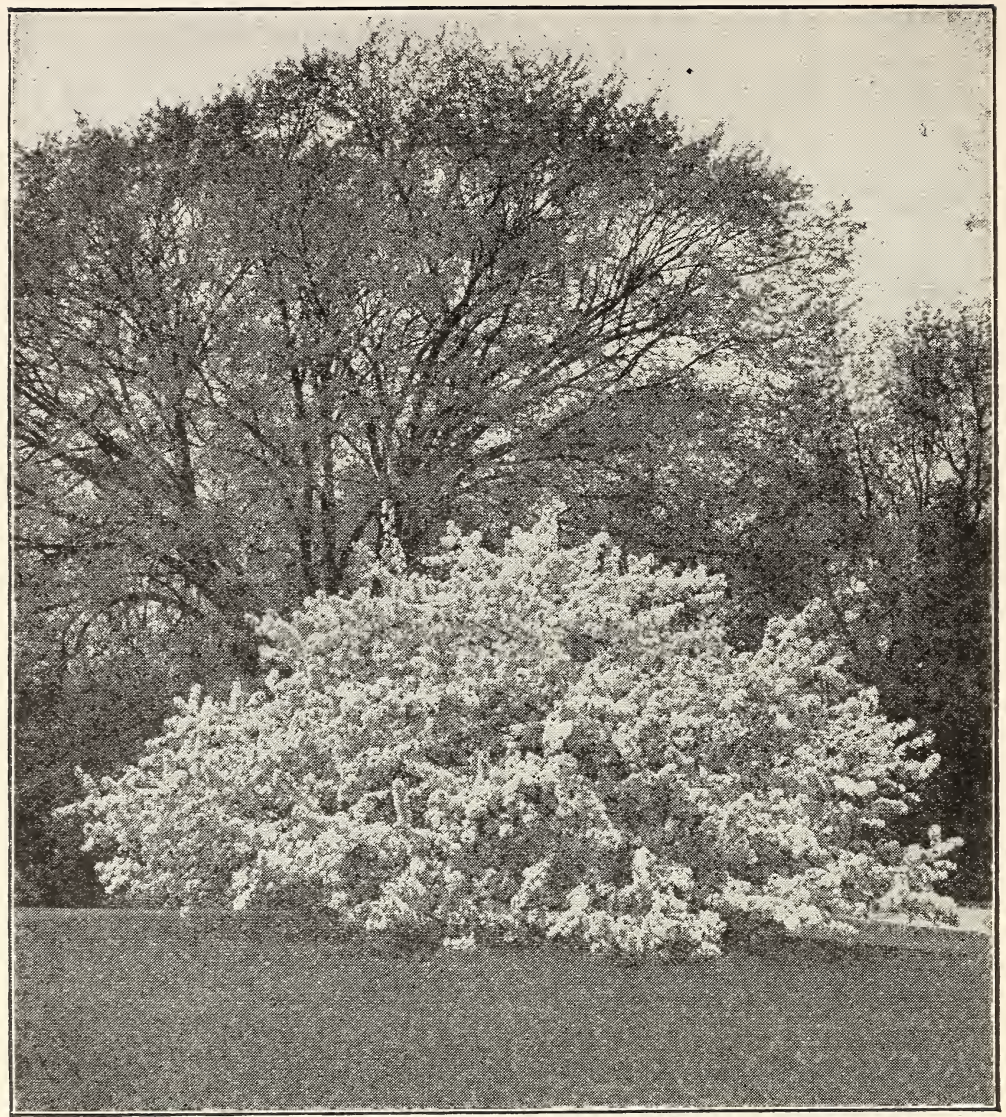

MALUS FLORIBUNDA, Japanese Flowering Crab.

MALUS SARGENTI, Sargent Crab.

Very dwarf spreading Japanese variety. Pale straw-color flowers with bright yellow anthers. Scarlet fruit hanging till Spring. 1 year from grafts.

MALUS SCHEIDECKERI, Scheidecker Crab.

Small tree of pyramidal habit, with small pink flowers in great profusion. 1 year from grafts, 3-4 feet.

MALUS SIEBOLDI (toringo), Toringo Crab.

Latest of the Asiatic Crabs to flower; bright red flower-buds and white flowers in greatest profusion. Large bright red, lustrous, persistent fruit. 1 year from grafts.

MALUS SIEBOLDI CALOCARPA.

"One of the handsomest (crabs) in the Arboretum, both in Spring and Autumn." Iarge pink and white flowers, brilliant scarlet fruit, half-inch in diameter. 1 year from grafts.

MALUS SPECTABILIS, Chinese Flowering Crab.

Tall shrub or small tree, large pink semi-double flowers, mediumsize yellow fruit. 1 year from grafts.

MALUS ZUMI, Zumi Crab. Pink and white flowers, bright scarlet fruit. 1 year from grafts, 3-4 feet. 
MENZIESIA PILOSA, Allegheny Menzlesia. Each

MORUS ALBA, White Mulberry. $12-18$ in. $\quad \$ .60$
$18-24$ in. $\quad .75$

MYRICA CAROLINENSIS, Northern Bayberry.

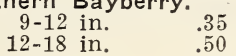

MYRICA GALE, Sweetgale.

\section{8-24 in. \\ $2-3 \mathrm{ft}$.}

OSTRYA VIRGINIANA, American Hophornbeam Seedlings $9-12$ in.

OXYDENDRUM ARBOREUM, Sourwood.

$$
\begin{array}{r}
12-18 \mathrm{in} . \\
18-24 \mathrm{in} . \\
2-3 \mathrm{ft} . \\
3-4 \mathrm{ft} . \\
4-5 \mathrm{ft} .
\end{array}
$$

PHELLODENDRON PHELLODENDRON AMURENSE, Amur

\section{Seedlings 6-9 in.}

PHELLODENDRON

\section{ACHALINEN}

\begin{abstract}
6-9 in.
\end{abstract} $2-3 \mathrm{ft}$. $3-4 \mathrm{ft}$. $4-5 \mathrm{ft}$.
10

$\$ 5.40$

6.75

3.60

2.70

4.50

4.50

9.00

2.10

2.40

3.60

5.40

9.00

13.50

9.00

1.50

25
100

$\$ 48.00$

60.00

24.00

39.00

39.00

81.00

21.00

30.00

48.00

81.00

120.00

ktree.

1.00
Corktree.

in Corktree.

12.00

12.00

81.00

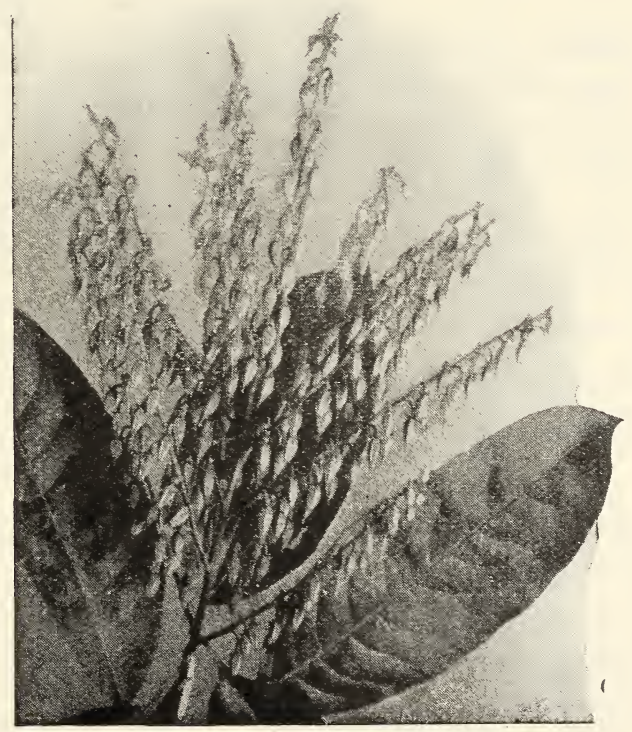

OXYDENDRUM ARBOREUM, Sourwood.

A small tree with beautiful ball-like flowers, resembling the Japanese Andromeda. Gorgeous autumn coloring. 
PHILADELPHUS CORONARIUS, Sweet Mockorange.

$\begin{array}{rrrrr}1 \mathrm{yr} . & 12-18 \mathrm{in.} & \text { Each } & 10 & 100 \\ 18-24 \mathrm{in} . & .25 & 2.10 & 18.00 \\ 2-3 \mathrm{ft} . & .60 & 3.60 & 32.40 \\ 3-4 \mathrm{ft} . & 1.00 & 5.40 & \\ & 9.00 & \end{array}$

PHILADELPHUS CORONARIUS GRANDIFLORUS, Big Mockorange.

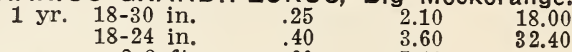

PHILADELPHUS LEMOINE1, Lemoine Mockorange.
2 yr. $10-18$ in.
18-24 in.
.30

5.40

32.40

HORTICULTURAL VARIETIES OF PHILADELPHUS.

Double (coronarius florepleno).

$\begin{array}{lllll}\text { Zeyher (zeyheri) } & 1 \mathrm{yr} . & 1-2 \mathrm{ft} . & .25 & 2.10 \\ & 1 \mathrm{yr} . & 12-18 \mathrm{in.} & .25 & 2.10\end{array}$

PIERIS MARIANA, Staggerbush.

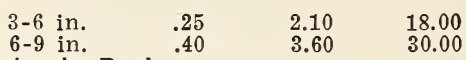

POPULUS NIGRA ITALICA, Lombardy Poplar.

$6-8 \mathrm{ft}$. $\quad .75 \quad 6.75 \quad 60.00$

POPULUS SIMONI, Simon Poplar.

$8-10 \mathrm{ft}$. $\quad 1.00$

$9.00 \quad 81.00$

PRUNUS AMERICANA, American PIum. Seedlings $9-12 \mathrm{in}$.

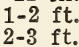

$3-4 \mathrm{ft}$.

4-5 ft.

PRUNUS BESSEYI, Bessey Cherry.

13.50

1.50

2.40

4.50

6.75

9.00

PRUNUS HORTULANA, Hortulan PIum.

$4.50 \quad 39.00$

PRUNUS MARITIMA, Beach PIUM.

.50

5.40

$1-2 \mathrm{ft} . \quad .60 \quad 5.40$

PRUNUS MUNSONIANA, Wildgoose Plum. Seedlings 6-9 in.

1.50

$\begin{array}{lll}1-2 \mathrm{ft} . & .30 & 2.40\end{array}$

12.00

18.00

PRUNUS NIGRA, Canada PIUm.

6-15 in.

.30

2.40

PRUNUS ORTHOSEPALA.

12-18 in.

.40

3.60

30.00

PRUNUS PUMILA, Sand Cherry.

18-24 in.

.40

2-3 $\mathrm{ft}$.

PRUNUS REVERCHONI, HOg PIUM.

$$
\text { 3-6 in. }
$$

.60

3.60

5.40

30.00

48.00

PRUNUS TOMENTOSA, Nanklng Cherry.

1.50

12.00

$$
\begin{aligned}
& \text { Seedlings 18-24 in. } \\
& \text { 18-24 in. } \\
& \text { 2-3 } \mathrm{ft} \text {. }
\end{aligned}
$$

2.40

5.40

HORTICULTURAL VARIETIES OF PRUNUS.

Double Pinkflowering Almond (trichostyla sinensis).

Double Whiteflowering Almond (glabro albiplena).

RHAMNUS CATHARTICA, Common Buckthorn.

.756 .75

RHAMNUS DAHURICA, Dahurian Buckthorn.

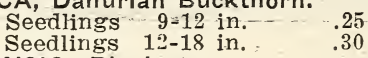

.251 .50

12.00

2.10

2.40

18.00

RHODORA CANADENSIS, Rhodora 
RHODOTYPOS KERRIOIDES, Jetbead. Seedlings $\begin{array}{r}6-9 \\ 10-15\end{array}$ $1-2 \mathrm{ft}$.

RHUS COPALLINA, Shining Sumac. $1-2 \mathrm{ft}$

RHUS GLABRA, Smooth Sumac. $2-3 \mathrm{ft}$. 2-3 ft. Each

RHUS TYPHINA, Staghorn Sumac. $2-3 \mathrm{ft}$. ROBINIA KELSEYI, Kelsey Locust. 1-2 ft. ROSA ACICULARIS, Prickly Rose.

$$
12-18 \text { in. }
$$

18-24 in.

ROSA CANINA, Dogbrier.

$$
\text { 12-18 in. }
$$

ROSA GYMNOCARPA, Bald-hip Rose.

ROSA HUGONIS, Hugo Rose.

ROSA LUCIDA, Virginia Rose.

$$
\text { 12-18 in. }
$$

ROSA LUCIDA ALBA, White Virginia Rose.

ROSA MULTIFLORA, Japanese Rose.

$$
\text { Seedlings } \begin{array}{cc}
6-9 & \text { in. } \\
& 2-3 \mathrm{ft} .
\end{array}
$$

ROSA MULTIFLORA CATHAYENSIS, Cathay Rose.

ROSA NITIDA, Bristly Rose.

.25

ROSA RUBIGINOSA, Sweetbrier.

ROSA RUgosA (ferox), Rugosa Rose.

ROSA SETIGERA, Prairie Rose.

ROSA SPINOSISSIMA, Scotch Rose.

RUBUS ODORATUS, Flowering Raspberry.

SALIX HUMILIS, Pralrie Willow.

$$
1-2 \mathrm{ft} \text {. }
$$

.40

SALIX PENTANDRA, Laurel Willow.

$$
2-3 \mathrm{ft} \text {. }
$$

.40

SALIX TRISTIS, Dwarf Pussy WIIlow.

$$
1-2 \mathrm{ft} \text {. } .50
$$

SORBUS AUCUPARIA (europaea), European Mountain-ash.

$$
\begin{array}{lrr}
1-2 \mathrm{ft} & .40 & 3.60 \\
2-3 \mathrm{ft} & .60 & 5.40 \\
3-4 \mathrm{ft} & 1.00 & 9.00
\end{array}
$$

SORBUS COMMIXTA, Japanese Mountain-ash. 


$\begin{array}{cccccc}\text { SPIRAEA BILLIARDI, Billiard Spirea. } & \text { Each } & 10 & 100 \\ & 1 \text { yr. } 12-18 \text { in. } & .25 & 2.10 & 18.00 \\ & 18-24 \text { in. } & .40 & 3.60 & \\ \text { SPIRAEA BUMALDA, Bumalda Spirea. } & .50 & 4.50 & \\ 2 \text { yr. } 8-12 \text { in. } & .30 & 2.40 & \end{array}$

SPIRAEA FROEBELI, Froebel Spirea.

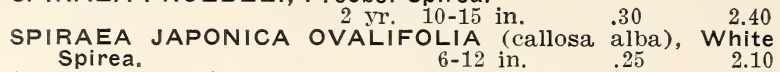

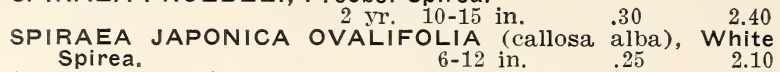

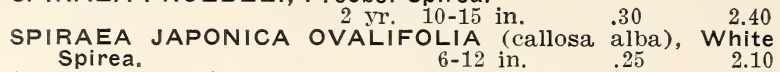

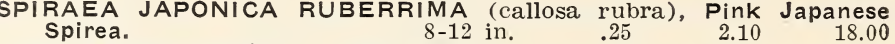
SPIRAEA PRUNIFOLIA, Bridalwreath.

$$
18-24 \text { in. } \quad .50 \quad 4.50
$$

SPIRAEA PRUNIFOLIA PLENA, Double Bridalwreath.

$\begin{array}{lcccc} & & & \\ \text { SPIRAEA SARGENTIANA. } & 10-15 \text { in. } & .30 & 2.40 & 21.00\end{array}$ SPIRAEA THUNBERGI, Thunberg Spirea.

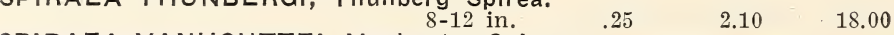

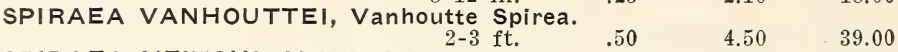

SPIRAEA VEITCHI, Veltch spirea.

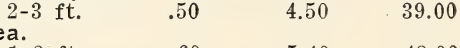

HORTICULTURAL. VARIETIES OF SPIREA.

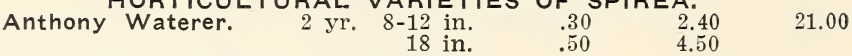
$\begin{array}{rrr}\text { White Billiard Spirea (billiardi alba) } & .50 & \\ 2-3 \mathrm{ft} . & .50 & 4.50 \\ 3-4 \mathrm{ft} . & .75 & 6.75\end{array}$

STEPHANANDRA FLEXUOSA, Cutleaf Stephanandra.

STEPHANANDRA FLEXUOSA, Cutleaf Stephanandra. $\underset{2-3 \mathrm{ft}}{\underset{6}{60}} \underset{5.40}{6.75}$

STEWARTIA PENTAGYNA, Mountain Stewartia. $\quad 9.00$

SYMPHORICARPOS OCCIDENTALIS, Western Snowberry. Seedlings $12-18$ in. $\quad .25 \quad 2.10$

SYMPHORICARPOS RACEMOSUS, Common Snowberry.

$\begin{array}{lll} & \\ 2-3 \mathrm{ft} & .60 & 5.40 \\ 3-4 \mathrm{ft} & .75 & 6.75 \\ \text { Coralberry. } & & \\ 2-3 \mathrm{ft} & .60 & 5.40 \\ 3-4 \mathrm{ft} & .75 & 6.75\end{array}$

48.00

SYMPHORICARPOS VULGARIS, Coralberry.

SYMPLOCOS PANICULATA (crataegoides), Asiatic Sweetleaf.

$$
\begin{array}{rrr}
9-12 \text { in. } & 1.00 & 9.00 \\
2-21 / 0 & 13.50
\end{array}
$$

SYRINGA JOSIKAEA, Hungarian Lilac. 6-12 in.

$1.50 \quad 13.50$

SYRINGA PERSICA, Persian Lilac.

$$
12-18 \text { in. } \quad .40 \quad 3.60
$$

SYRINGA VULGARIS, Common Lilac.

$2-3 \mathrm{ft}$. $\quad .60 \quad 5.40$

48.00

48.00

SYRINGA VULGARIS ALBA, Common White Lilac.

$\begin{array}{llr}2-3 \mathrm{ft} & .80 & 7.20 \\ 3-4 \mathrm{ft} & 1.25 & 11.25 \\ 4-5 \mathrm{ft} & 2.00 & 18.00\end{array}$

7.20

11.25

Mixed Hybrids.

\subsection{0}

48.00

63.00

$\begin{array}{rrr}18-24 \text { in. } & 1.00 & 9.00 \\ 2-3 \text { ft. } & 1.60 & 14.40 \\ 3-4 \text { ft. } & 2.75 & 24.00\end{array}$

TAMARIX HISPIDA, Kashgar Tamarix. 6-12 in. TILIA AMERICANA, American $\begin{gathered}\text { Linden. } \\ 3-4 \mathrm{ft} .\end{gathered}$ $10-12 \mathrm{ft}$.

ULMUS AMERICANA, American EIm.

$\begin{array}{rrr}5-6 \mathrm{ft} & .60 & 5.40 \\ 6-8 \mathrm{ft} & 1.00 & 9.00 \\ 8-10 \mathrm{ft} & 1.50 & 13.50 \\ 10-12 \mathrm{ft} & 2.50 & 22.50 \\ 12-14 \mathrm{ft} & 4.00 & 36.00 \\ 14-16 \mathrm{ft} & 5.00 & 45.00\end{array}$


VACCINIUM CORYMBOSUM, Highbush Blueberry.

Fine stock, grown from seed and cuttings and transplanted several times. This is the Blueberry of commerce, but not the new Coville Hybrids. Also it is one of the finest of ornamentals. A success commercially only on acid soils. Each

$\begin{array}{rrrrr} & & & \\ & 3-6 \text { in. } & .30 & 2.40 & 21.00 \\ 6-9 & \text { in. } & .40 & 3.60 & 30.00 \\ 9-12 \text { in. } & .50 & 4.50 & 39.00 \\ 12-18 \text { in. } & .80 & 7.20 & 63.00 \\ \text { Clumps } 18-24 \text { in. } & 1.00 & 9.00 & 81.00 \\ \text { Clumps } & 2-3 \text { ft. } & 2.00 & 18.00 & \\ \text { Clumps } & 3-4 \mathrm{ft} . & 3.50 & 31.50 & \end{array}$

VACCINIUM PALLIDUM, Blueridge Blueberry.

A very fine variety from the Carolina Mountains. Large, sweet berries with a fine "bloom" when ripe. Fine ornamental.

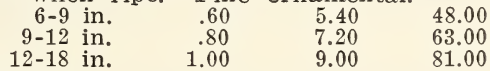

VACCINIUM STAMINEUM, Deerberry. $12-18$ in. $\quad .50 \quad 4.50 \quad 39.00$ 18-24 in. $\quad .75 \quad 6.75 \quad 60.00$

VIBURNUM ACERIFOLIUM, Mapleleaf VIburnum.

VIBURNUM AMERICANUM, American Cranberrybush.

VIBURNUM CASSINOIDES, Withe-rod.

$\begin{array}{rrrr}\text { CASSINOIDES, Withe-rod. } & & 6.75 & 60.00 \\ \text { Seedlings } 18-24 \mathrm{in.} & .25 & 2.10 & 18.00 \\ 2-3 \mathrm{ft} . & .60 & 5.40 & 48.00 \\ 3-4 \mathrm{ft} . & .80 & 7.20 & 63.00 \\ 4-5 \mathrm{ft} . & 1.50 & 13.50 & 120.00\end{array}$

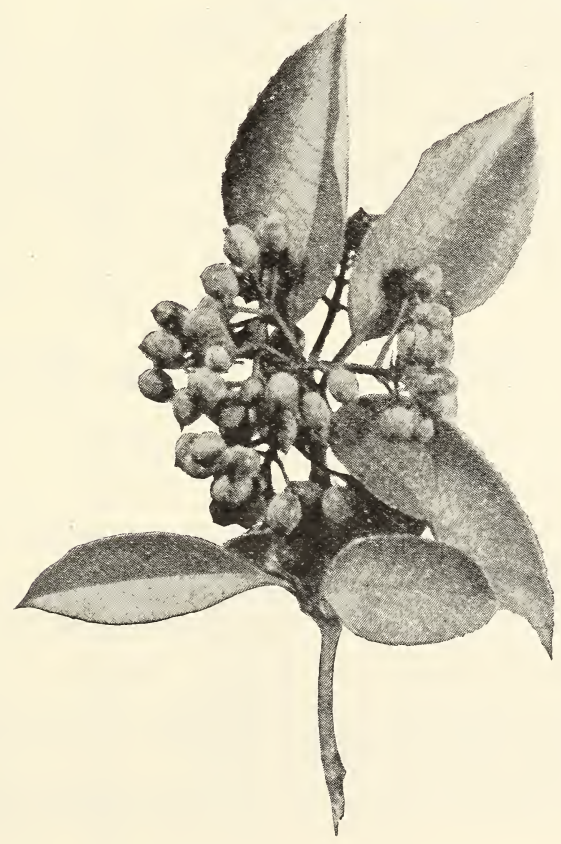


VIBURNUM DENTATUM, Arrowwood.

$\begin{array}{rr}\text { Seedlings } & 3-6 \text { in. } \\ \text { Seedlings } & 9-12 \text { in. } \\ 9-12 & \mathrm{in} . \\ 12-18 & \mathrm{in} . \\ & 18-24 \mathrm{in} . \\ \text { Clumps } & 5-7 \mathrm{ft} .\end{array}$

VIBURNUM LANTANA, Wayfaring-tree.

Each

.15

.25

.30

.40

.60

2.00

$1-2 \mathrm{ft}$.

VIBURNUM LENTAGO, Nannyberry.

$$
\begin{array}{rr}
18-24 \text { in. } & .40 \\
2-3 \text { ft. } & .60 \\
3-4 \mathrm{ft} . & 1.00
\end{array}
$$

VIBURNUM OPULUS, European Cranberrybush.
10

.75

1.50

2.40

3.60

5.40

18.00

5.40

3.60

5.40

9.00

48.00

3.60

5.40

6.75

.75

100

6.00

12.00

21.00

30.00

48.00
3.60

4.50

9.00

1.00

2.10

6.75

11.25

1.25

9.00

2.40

21.00

$2.40 \quad 21.00$

$2.10 \quad 18.00$

4.50

6.75

30.00

39.00

18.00

.25 T.10

Desbois (hybrida desboisi), 10-15 in.

Eva Rathke.

$6-12$ in.

$2-3 \mathrm{ft}$.

ZANTHORHIZA APIIFOLIA, Yellowroot.

6-12 in.

12-18 in.

.30

.60

2.40

5.40

21.00

.40

.50

3.60

4.50

30.00

39.00

\section{VINES, CREEPERS AND CLIMBERS}

$\begin{array}{rrrr}\text { ACTINIDIA ARGUTA, Bower Actinidia. } & \text { Each } & 10 & 100 \\ 2 \text { year } & 1.00 & 9.00 & \end{array}$ AKEBIA QUINATA, Fiveleaf Akebia.

3 year $\quad .60 \quad 5.40$

AMPELOPSIS HETEROPHYLLA, Porcelain Ampelopsis.

1 year $\quad .40 \quad 3.60$

AMPELOPSIS QUINQUEFOLIA, Virginia Creeper.

4.50

AMPELOPSIS QUINQUEFOLIA ENGLEMANNI, Engelmann Creeper. AMPELOPSIS QUINQUEFOLIA ENGLEMANNI, Engeimann Creeper.

AMPELOPSIS TRICUSPIDATA, Japanese Creeper.

Strong $\quad .50 \quad 4.50$

AMPELOPSIS VITACEA, Thicket Creeper.

$15-18$ in. $\quad .75 \quad 6.75$

ARISTOLOCHIA SIPHO, Dutchmans-pipe.

CELASTRUS ORBICULATUS PUNCTATUS, Christmas Bittersweet.

$2-3 \mathrm{ft}$. $.50 \quad 4.50 \quad 39.00$ 
CLEMATIS PANICULATA, sweet Autumn Clematis.

$\begin{array}{ccc} & \text { Each } & 10 \\ \text { medium } & .40 & 3.60 \\ 2 \text { year } & .75 & 6.75\end{array}$

CLEMATIS LIGUSTICIFOLIA, Western Virgins-bower.

Nestern
Strong
Strgins-bower.

CLEMATIS VIRGINIANA, Virgins-bower.

Small $\quad .25 \quad 2.10$

100

.75

EUONYMUS RADICANS, Wintercreeper.

rcreeper

$60 \quad 5.40$

18.00

EUONYMUS RADICANS VEGETUS, Bigleaf Wintercreeper.

HYDRANGEA PETIOLARIS, Climbing Hydrangea.

5 -inch pots 2.00

LYCIUM CHINENSE, Chinese Matrimony-vine.

1 year $3-4 \mathrm{ft}$. 25

2.10

18.00

ROSA, Rose.

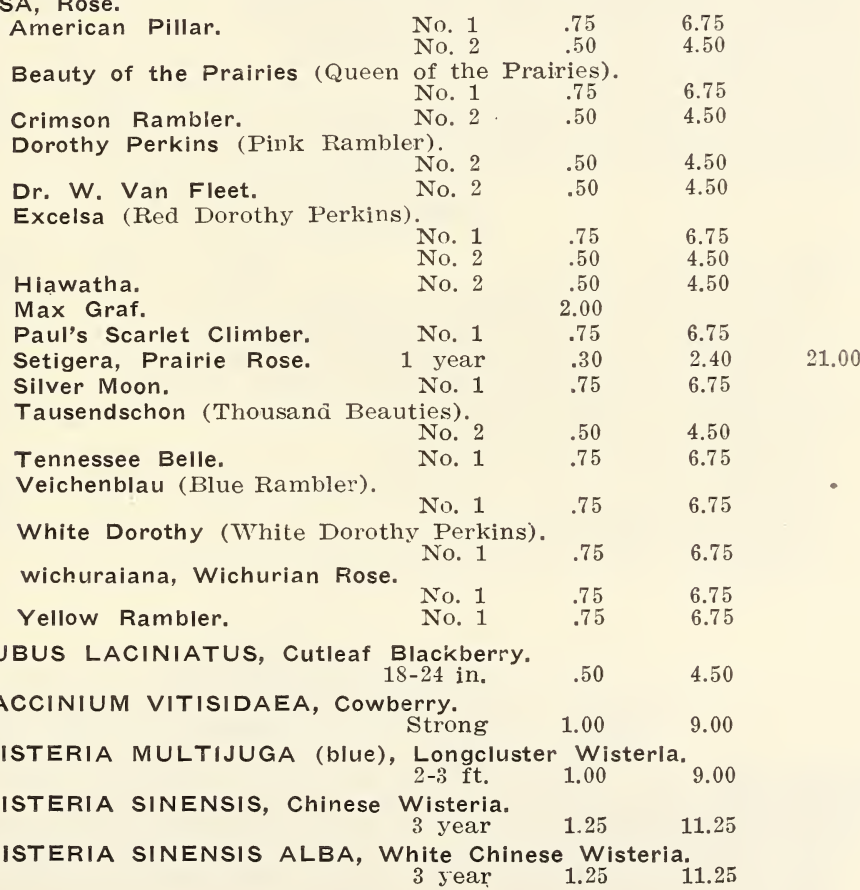

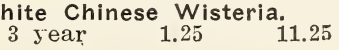

"HARDY NEW ENGLAND GROWN-BEST BY TEST" 


\section{HARDY HERBACEOUS PERENNIALS}

In this list will be found a collection of hardy herbaceous perennials that will give a good succession of bloom from early spring to late autumn. Nearly all are of easy culture. The usual list of herbaceous perennials offered in American catalogs can be secured and shipped with other orders, so that customers may feel safe in getting full collections.

Prices of herbaceous perennials, unless otherwise noted, $30 \mathrm{c}$ each; $\$ 2.40$ per $10 ; \$ 21.00$ per 100 .

ACHILLEA PTARMICA, var. Pearl.

Each

100

ANEMONE JAPONICA, var. Queen Charlotte.

ASTERS, in variety.

CALTHA PALUSTRIS, Marshmarigold.

CHELONE GLABRA, White Turtlehead.

CHELONE LYONI, Pink Turtlehead.

CHRYSANTHEMU'M COREANUM, Korean Chrysanthemum.

CHRYSANTHEMUM, hardy named varieties.

CIMICIFUGA RACEMOSA, Cohosh Bugbane.

CONVALLARIA MAJALIS, Lily-of-the-Valley.

CORNUS CANADENSIS, Bunchberry.

CYPRIPEDIUM ACAULE, Pink Ladyslipper.

DIANTHUS, var. Her Majesty, pure white.

DIANTHUS, var. Homer, dark red.

DICENTRA EXIMIA, Fringed Bleedingheart.

DICENTRA SPECTABILIS, Bleedingheart.

.35
1.00 $\quad 2.70$

24.00

DIONAEA MUSCIPULA, Venus Flytrap.

DROSERA ROTUNDIFOLIA, Roundleaf Sundew.

\section{FERNS}

Prices of Ferns unless otherwise noted,

\section{Each}

10

100

Adiantum pedatum, American Maidenhair Fern.

Athyrium (Asplenium) filixfemina, Lady Fern.

Dennstedtia (Dicksonia) punctilobula, Hay-scented Fern.

Dryopteris (Aspidium) marginalis, Leather Woodfern.

Dryopteris noveboracensis, New York Fern.

Dryopteris spinulosa, Toothed Woodfern.

Dryopteris thelypteris, Marshfern.

Onoclea sensibilis, Sensitive Fern.

Osmunda cinnamomea, Cinnamon Fern.

- Osmunda claytoniana, Interrupted Fern.

Osmunda regalis, Roval Fern.

.40

.40

.40

3.60

3.60

3.60

33.00

33.00

Polypodium vulgare, Common Polypody.

33.00

Polystichum (Dryopteris) acrostichoides, Christmas Fern.

Pteretis (Onoclea) nodulosa, Ostrich Fern.

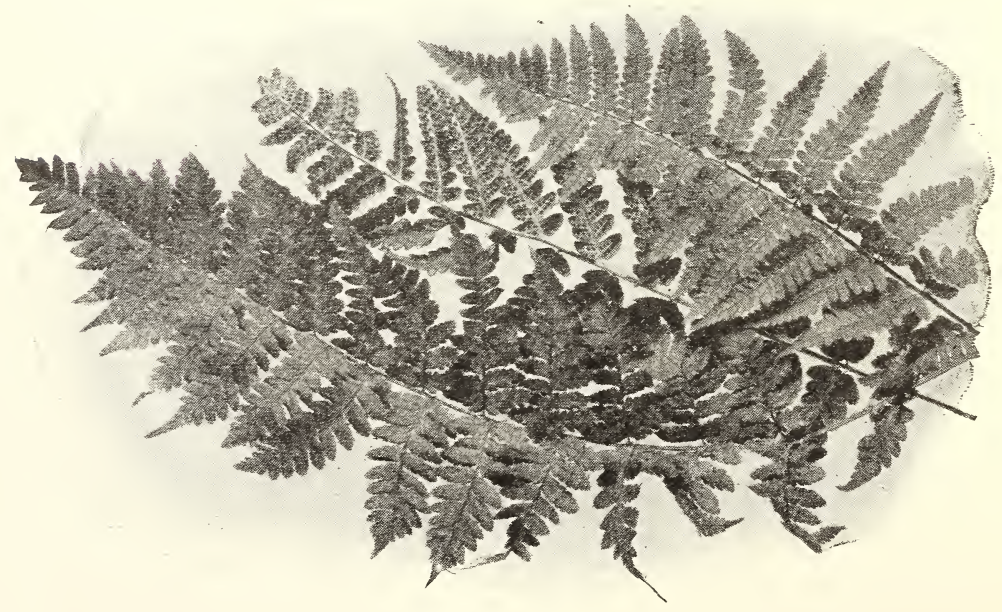


FILIPENDULA CAMTSCHATICA, Kamchatka Meadowsweet.

GALAX APHYLLA, Galax.

GILLENIA STIPULATA, Indian-physic.

HEMEROCALLIS DUMORTIERI (sieboldi), Early Daylily.

HEMEROCALLIS FLAVA, Lemon Daylily. $\quad .40 \quad 3.60$

HEMEROCALLIS FULVA, Tawny Daylily.

HEMEROCALLIS THUNBERGI, Japanese Daylily.

HEPATICA TRILOBA, Roundlobe Hepatica.

HOSTA (Funkia) LANCEFOLIA, Lanceleaf Plantainlily.

HOSTA (Funkia) PLANTAGINEA GRANDIFLORA, Big Plantainlily.

IRIS CRISTATA, Crested Iris.

IRIS GERMANICA, German Iris, named varieties.

IRIS GERMANICA, German Iris, mixed varieties.

IRIS KAEMPFERI, Japanese Iris, finest mixed colors.

IRIS PALLIDA, var. DaImatica.

IRIS PSEUDACORUS, Yellowflag Iris.

IRIS VERNA, Vernal Iris.

IRIS VERSICOLOR (virginica), Blueflag Iris.

LAMIUM MACULATUM, Spotted Deadnettle.

LIATRIS SPICATA, Spike Gayfeather.

LILIUM CANADENSE, Canada Lily.

LILIUM CAROLINIANUM, Carolina Lily.

LILIUM GRAYI, Grays Lily.

LILIUM HENRYI, Henry Lily.

LILIUM SUPERBUM, American Turkscap Lily.

$\$ 1.25 \$ 11.25 \$ \$ 102.00$

LILIUM TIGRINUM, Tiger Lily.

LYSIMACHIA NUMMULARIA, Moneywort.

OENOTHERA FRUTICOSA YOUNGI, Youngs Sundrops.

PAEONIA, Peony, selected colors.

PHLOX, named varieties in finest sorts.

PHLOX SUBULATA, Moss Phlox.

PHLOX, var. White Moss.

POLYGONATUM COMMUTATUM, Great Solomonseal.

PONTEDERIA CORDATA, Pickerelweed.

SANGUINARIA CANADENSIS, Bloodroot.

SEMPERVIVUM CALIFORNICUM.

SEMPERVIVUM FIMBRIATUM, Fringed Houseleek,

SEMPERVIVUM GLOBIFERUM, Globe Houseleek.

SEMPERVIVUM TECTORUM (robustum), Roof Houseleek.

SHORTIA GALACIFOLIA, Oconee-bells.

SOLIDAGO, Goldenrod in variety.

STENANTHIUM ROBUSTUM, Featherfleece.

STOKESIA LAEVIS (cyanea), Stokesia.

THERMOPSIS CAROLINIANA, Carolina Thermopsis.

TRILLIUM GRANDIFLORUM, Snow Trillium.

TYPHA LATIFOLIA, Common Cattail.

VINCA MINOR ALBA, White Common Periwinkle.

VIOLA CORNUTA, Tufted Pansy.

VIOLA PEDATA, Birdsfoot Violet.

YUCCA FLACCIDA, Weakleaf Yucca. 

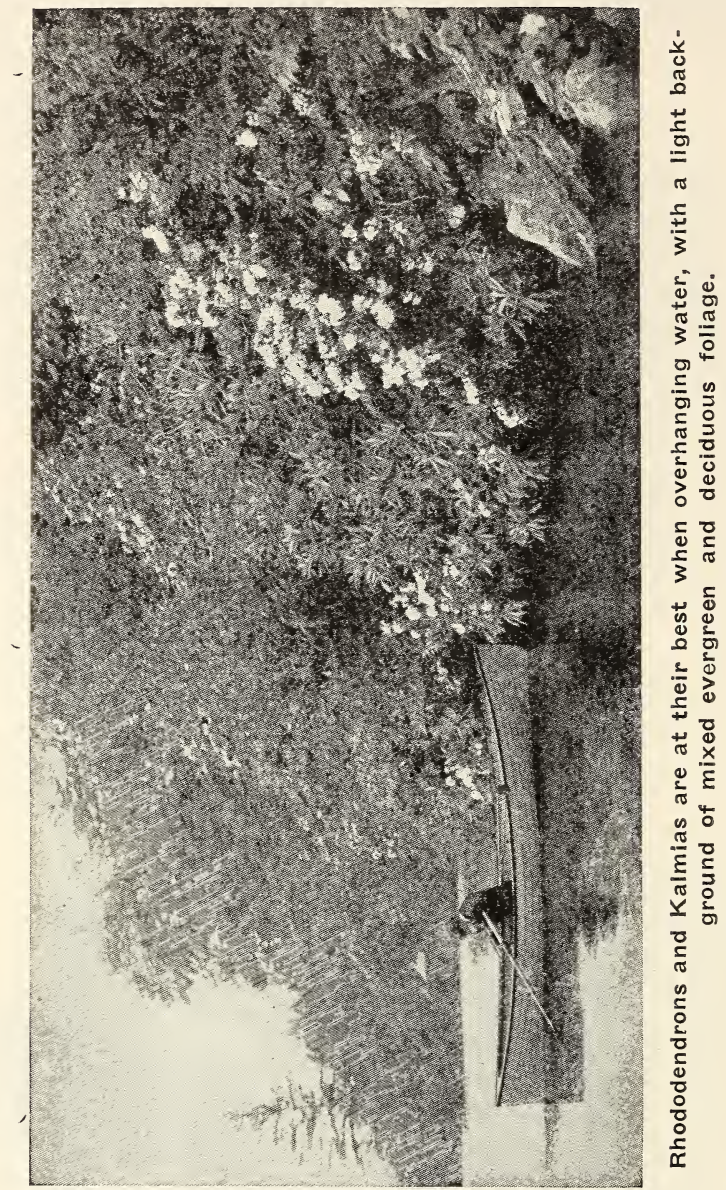


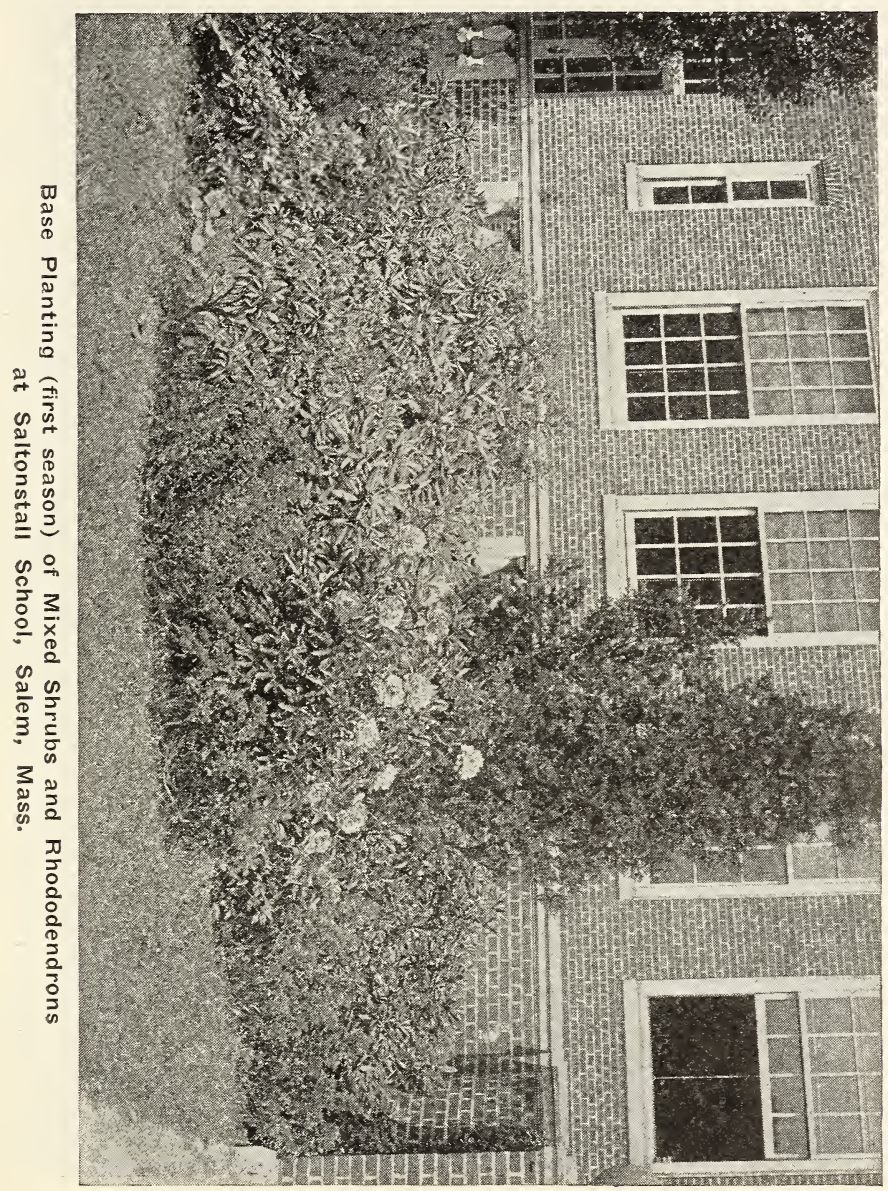




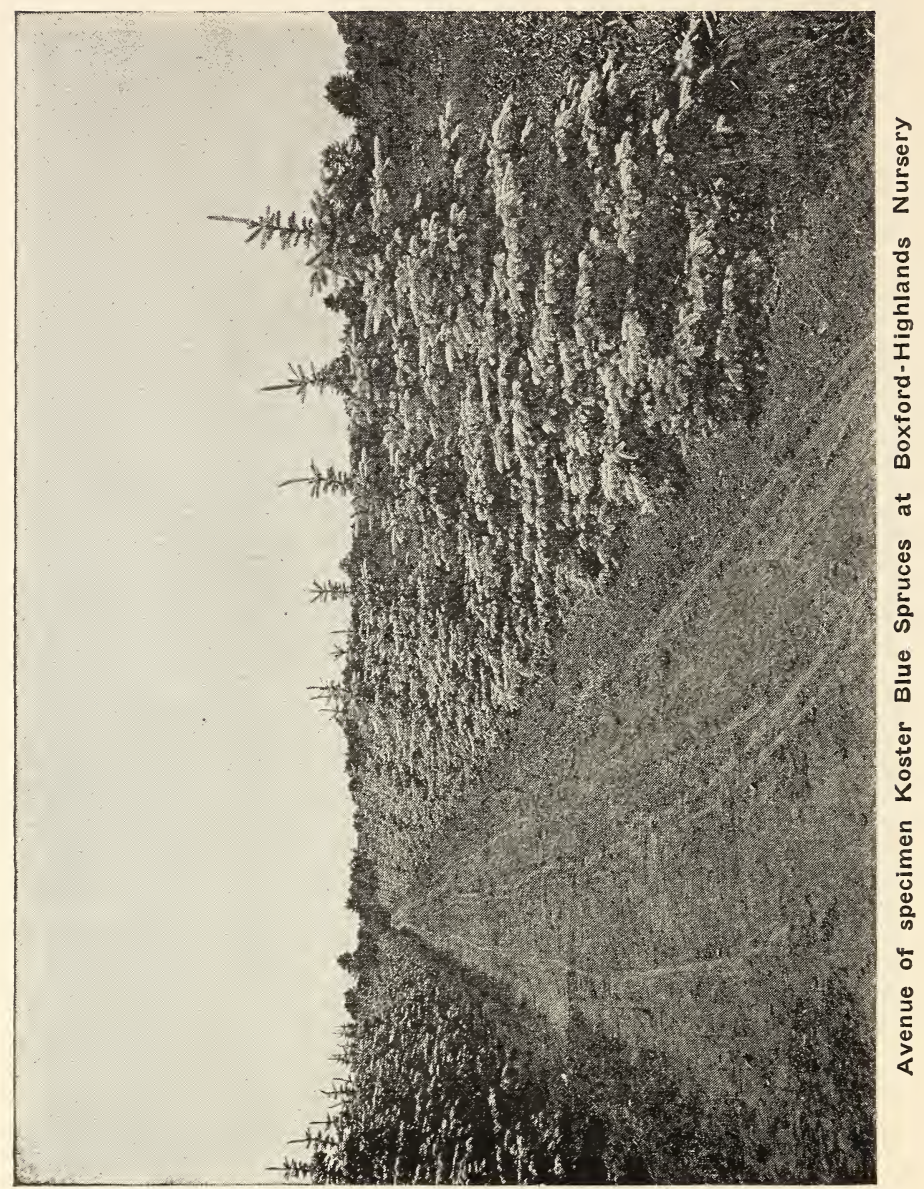


HARLAN P. KELSEY, SALEM, MASSACHUSETTS

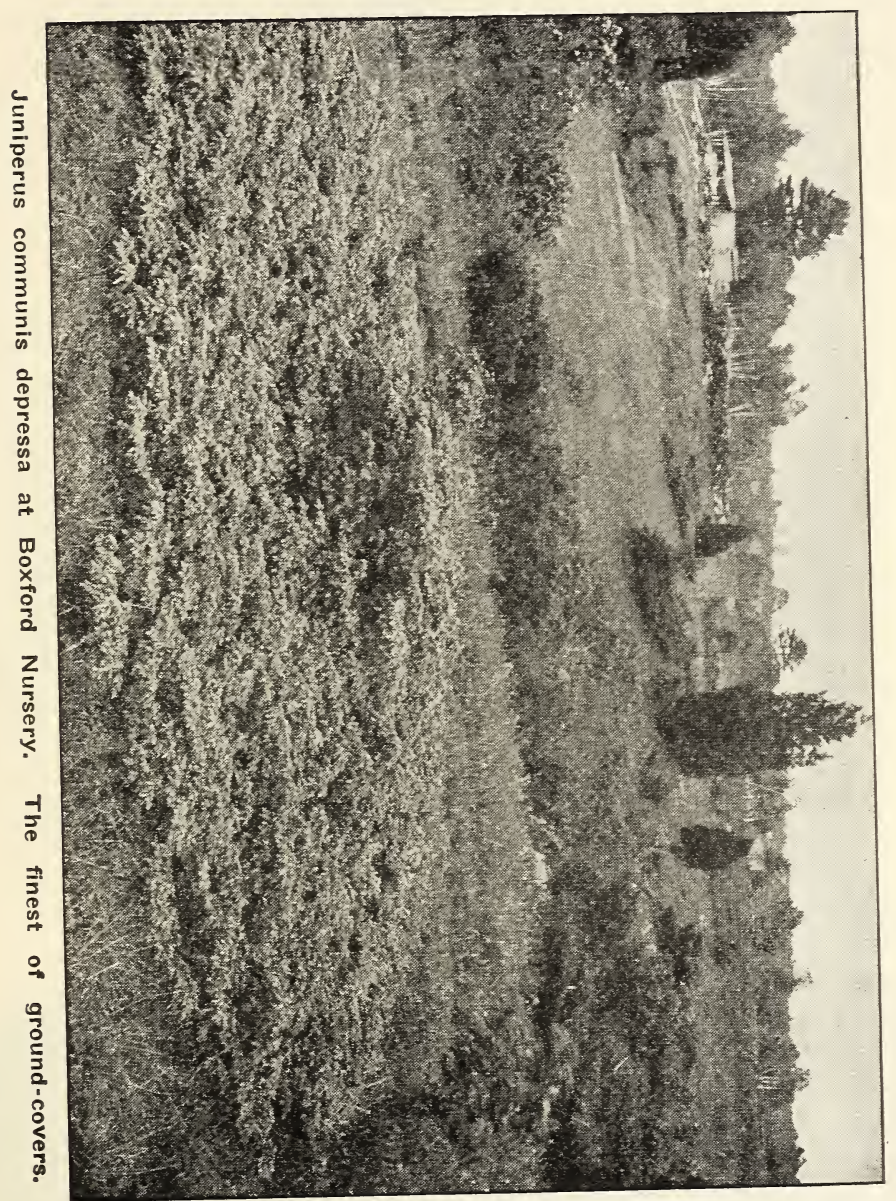




\section{KELSEY'S HARDY AMERICAN PLANTS}

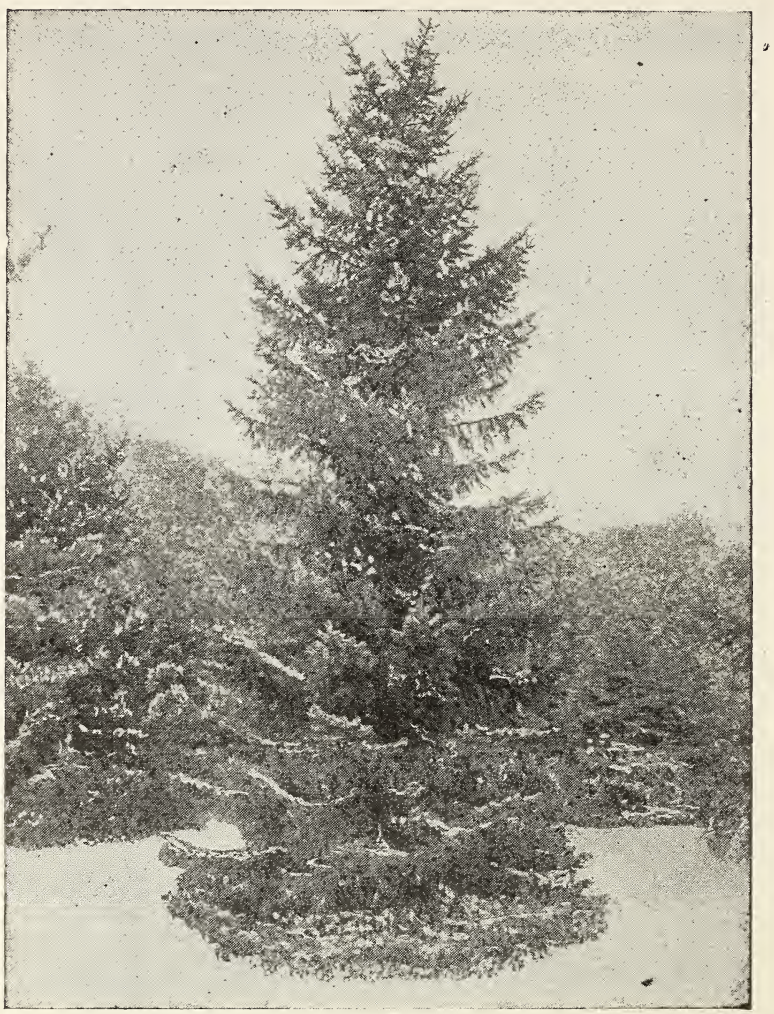

PICEA OMORIKA, Serbian Spruce.

One of the most beautiful and satisfactory of all the spruces. 


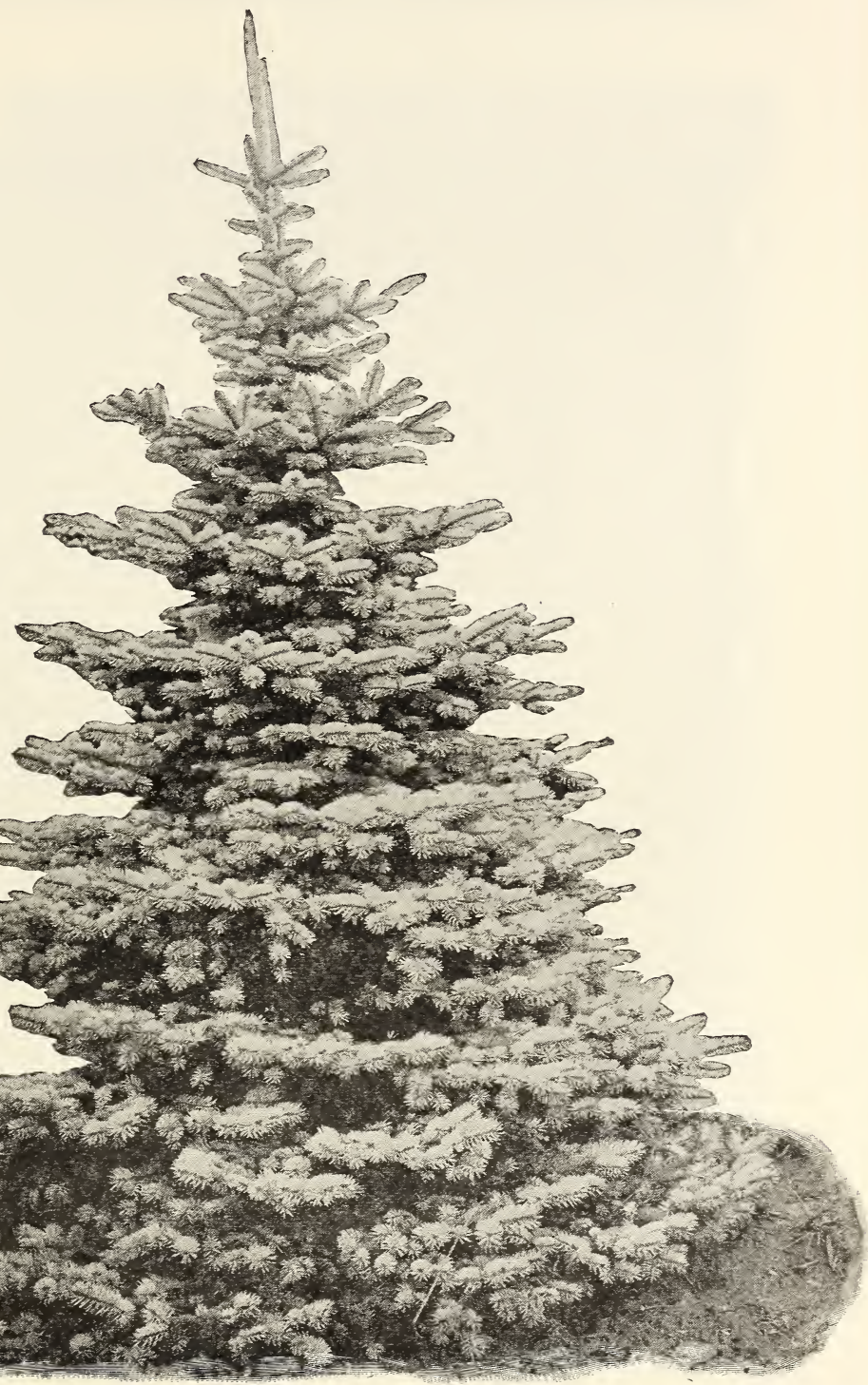

\section{SPECIMEN KOSTER BLUE SPRUCE.}

Photographed at Boxford-Highlands Nursery. We have hundreds just as perfect as this, up to 12 feet in height. 


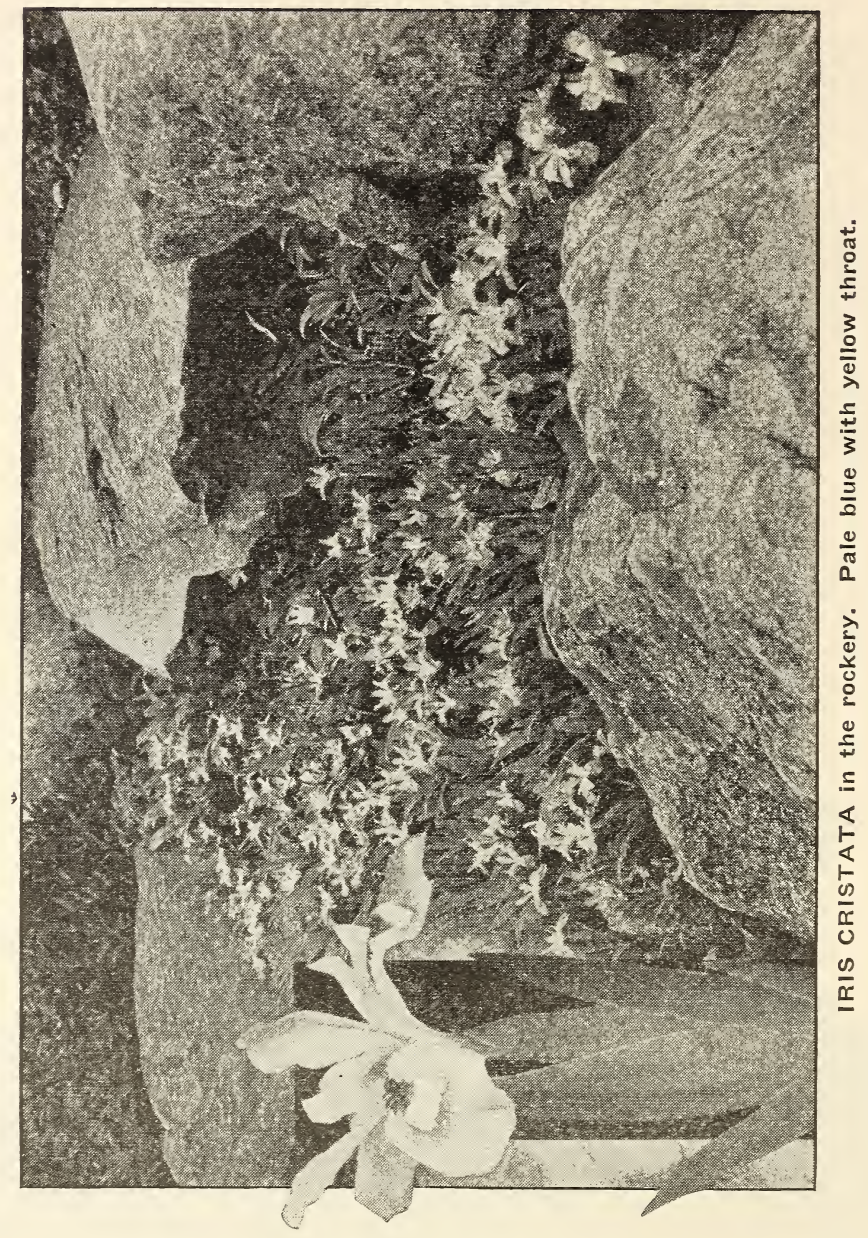




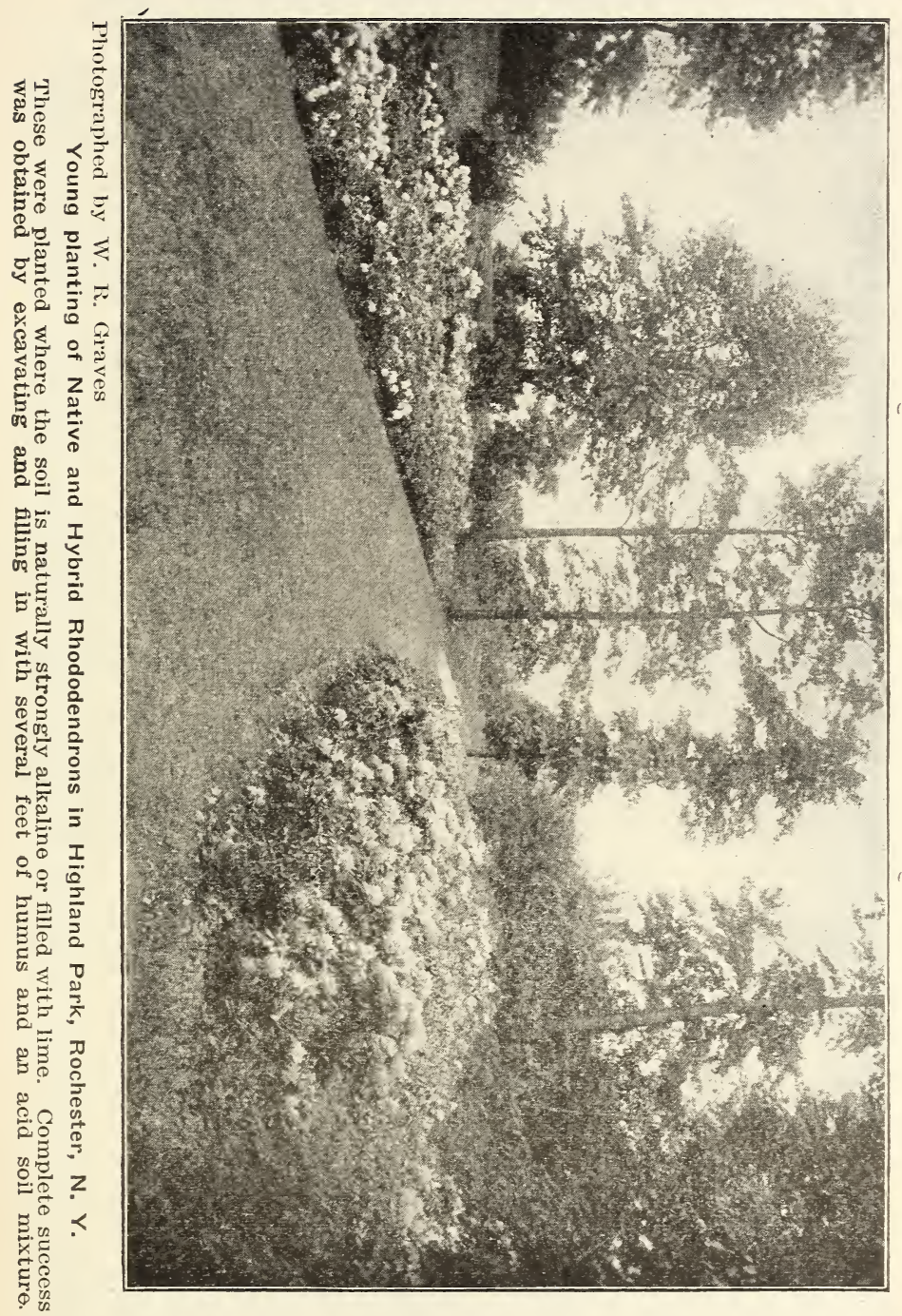




\title{
The Successful Rhododendron Bed
}

\author{
By Harlan P. Kelsey
}

This includes Rhododendrons, Kalmias, Azaleas, Leucothoes, Blueberries and other ericaceous genera and similar native and exotic plants, and often such "fillers" as Ferns, Lilies, etc., which delight in acid soil conditions and which are usually grouped together to make what is termed the "Rhododendron Bed."

Soil. This class of plants is most at home in somewhat shady and damp situations, and in a porous soil supplying plenty of humus and always showing more or less acid reaction. Limestone (alkaline) soils must be avoided, as a majority of ericaceous plants (Rhododendrons, Azaleas, Blueberries, etc.) are rarely if ever found growing naturally under such soil conditions. Sandy loam is favorable, but in all cases continuous supply of humus should be provided.

Creating Necessary "Acid" Conditions. Dr. Coville, United States Botanist of the Department of Agriculture, Washington, D. C., has made some very interesting greenhouse experiments which would seem to prove that acidifying soils by the application of aluminum sulfate makes it possible to grow these acid soil plants much more successfully. We are testing out this method on a large scale, and can no doubt give some definite conclusions in another year as to how this method will work in outdoor plantings.

It must be remembered, however, that application of acids will not take the place of humus. Others claim beneficial results by the application of tannic acid in dilution, but this also needs further experiments before the method can be generally recommended. Hardwood sawdust may be used as a mulch, and also ground peat moss or mull, which is imported from Holland, both having acid reaction.

The above experiments indicate that by suitable treatment, these beautiful ericaceous plants may sometimes be grown successfully on the alkaline soils of the Middle West.

Mulching. This means that the Rhododendron bed should have annually a heavy mulch of hardwood leaves, which is left on the year round to decay. Mulching also keeps the ground cool in summer and warm in winter and protects the fine feeding rootlets of the plants. Removing the mulching in spring to make the beds "look better" is one of the greatest causes of non-success in growing Rhododendrons and similar plants. No expert gardener would ever think of so doing.

Preparation of Bed. Unless conditions are naturally favorable, excavate two to three feet and fill with woods mold, "Kalmia peat," good loam, rotted field-sods, and perhaps a third in bulk of swamp muck or peat or similar soils. Make a tenth part of the mixture sharp sand, especially where the soil is too clayey. The center of the bed or plantation may be raised 6 to 12 inches above the surrounding ground, after allowing for natural settling.

Planting. Plant the same depth as before (shown by earth line or "colla.r" on stem) and firmly press soil around roots with the foot, but don't pack the earth too solid,-Rhododednrons are not telegraph poles. "Fillers," including Lilies and other bulbs and smaller groundcovering species, should be planted after the larger plants are all in and properly spaced. Then soak the ground and apply the mulching.

Winter Protection. If convenient, protect them with pine or other evergreen boughs, particularly where exposed to the sun and wind; yet Rhododendrons rarely suffer in the latitude of Boston or Buffalo, if properly planted and mulched. In the latitude of Ottawa and Quebec, Canada, a board fencing may be placed around the edge of the bed and much heavier temporary mulching of straw, etc., filled in almost or quite to the tops of the plants. It is rarely necessary to build a board cover, except on southern exposures to prevent sunburn, or with tender varieties not suitable for general planting, and even then evergreen boughs are preferable. Good ventilation must be provided. 
Selecting the Location. For the Rhodendron bed a northern exposure is preferable, especially in low elevation in the South, or elsewhere where freezing and thawing is quite continual. A direct winter sun on the frozen leaves of any broadleaf evergreen often kills outright or spoils the foliage. The north side of the building, wall, woods or hill is always preferable, and windswept locations should be avoided unless proper measures are taken to check the heavy winds.

In Limestone Soils. Excavation is imperative, and fresh soil showing acid reaction substituted. This can be successfully done. A striking example is shown in Highland Park, Rochester, N. Y., where one of the most beautiful Rhododendron and Azalea beds in America has been constructed and planted in a location originally of a heavy limestone nature. Blueberry culture is not a success in limestone soils.

Enemies of the Rhododendron. Rhododendrons, Kalmias, and similar plants have few enemies. The only serious one I know is the Lace-wing Fly, which is native from New England throughout the Alleghanies, and is found on Kalmia angustfolia, Rhododendron maximum, Kalmia latifolia, and occasionally on almost any broadleaf evergreen or deciduous tree or shrub. This pest appears in early spring on the under side of the leaves and gets its sustenance by sucking the sap. The leaves turn brown, giving the plant a ragged, unkempt appearance. It is easily disposed of by spraying the under side of the leaves, using a very fine nozzle, with an emulsion of ten gallons of whale-oil soap to one hundred gallons of water. While the Lacewing Fly is more at home on Rhododendron maximum, it does not hesitate to attack all other species to a greater or less extent. Plants in the shade are rarely infested to any great degree.

The Use of "Fillers." For the best landscape effects, as well as providing a continual succession of bloom throughout the season and actually protecting the Rhododendrons and supply "feathered" edge to the ground, a large variety of shrubs and plants may be employed with the finest results. In fact, the planting of Rhododendrons without the use of "filler" or "edging" plants may give harsh, formal effects, which are neither desirable nor natural in any way. In the use of "fillers" great care must be taken as to time of blooming and color effects, so they do not clash. It is surprising how many "filler" plants can be used without detracting from the broad evergreen effect, and yet supplying an amazing amount of interesting detail and a continuous show of blossoms against a beautiful Rhododendron leaf background.

Some of the Best "Fillers" and "Edging" Plants. Andromeda polifolia, Chamaedaphne calyculata (Leatherleaf), Leiophyllum buxifolium, L. prostratum, Ilex glabra (Inkberry), Leucothoe ca.tesbaei, Pieris floribunda, Taxus canadensis (Canada Yew), Galax aphylla, Gaultheria procumbens, Houstonia (Bluets), Mitchella repens (Partridgeberry), Shortia galacifolia (Oconee-bells), Vinca minor (Periwinkle), Zanthorhiza apiifolia (Yellowroot), Lilies, Trilliums, Erythroniums (Dogtooth Violets). Ferns in great variety, Violets, Dicentra eximia (Fringed Bleedingheart), Iris in great variety, particularly pseudacorus and Japanese, Azaleas in variety, Ilex verticillata, Aronias (Chokeberry) in variety, and many other "berry-bearing" shrubs. Jonquils and other spring bulbs may be used freely in the borders of plantations with charming results. 


\section{STANDARDIZED PLANT NAMES}

is authority for all names used in catalogs of Boxford-Highlands Nursery.

This new book is now rapidly being accepted as the standard authority for all dealings in and current literature about plants in the United States. It is not a new and different scientific system of nomenclature, but a workable harmonization of the present confusion, and is the first co-operative attempt of the leading trade and amateur organizations to so standardize plant names as to make buying easy.

STANDARDIZED PLANT NAMES is published for the benefit and advantage of the American horticultural public, and sold at far below its actual cost,-compilation costs and publishers' profits are wholly absent. The book contains 546 double column pages, covers more than 40,000 entries, and by the type arrangement shows the approved scientific and the approved common name for all plants in American commerce, as well as the unapproved synonyms.

\section{STANDARDIZED PLANT NAMES IS AVAILABLE IN FOUR STYLES}

Standard Edition, bound in cloth for library and general use at. $\$ 5.00$

Pocket Edition, flexibly bound in Fabrikoid, printed on India or "Bible" paper (weighs but 11 ounces, barely a half-inch thick, fits

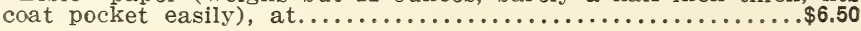

Interleaved Edition, which is the Standard edition with blank pages between the text pages for additions, at................\$6.50

Send order with remittance to

\section{HARLAN P. KELSEY, Secretary}

American Joint Committee on Horticultural Nomenclature,

SALEM, MASS ACHUSETTS 


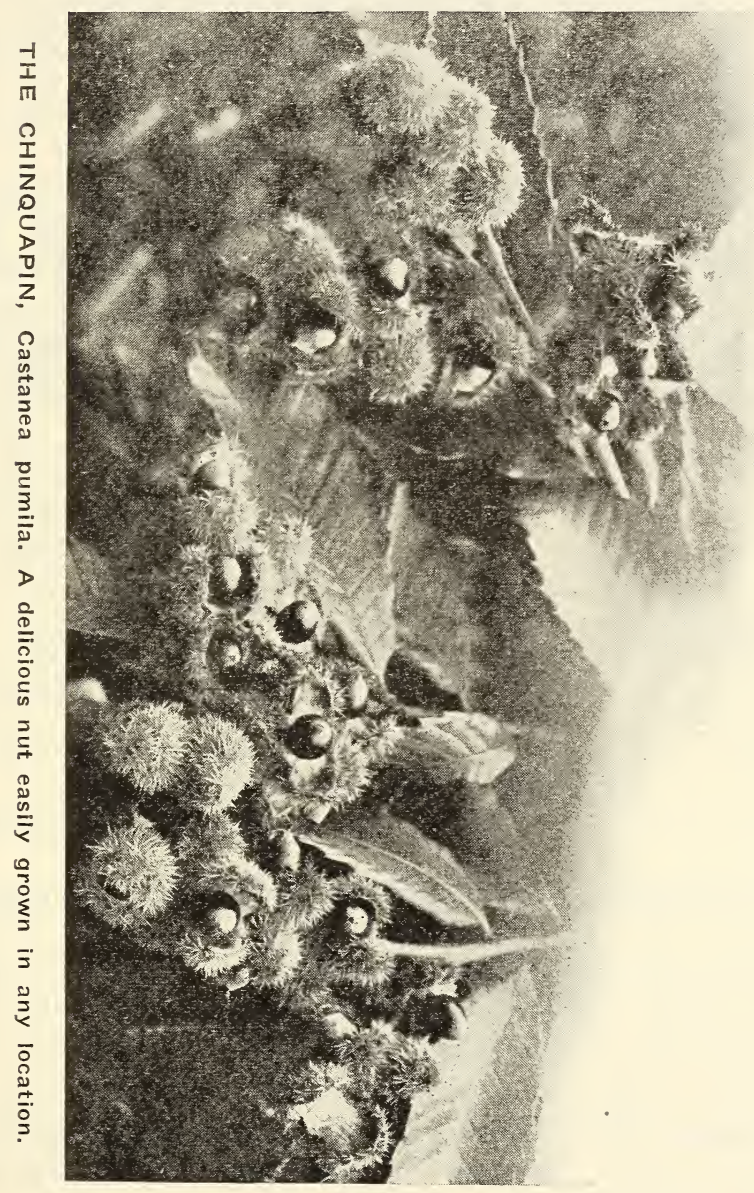




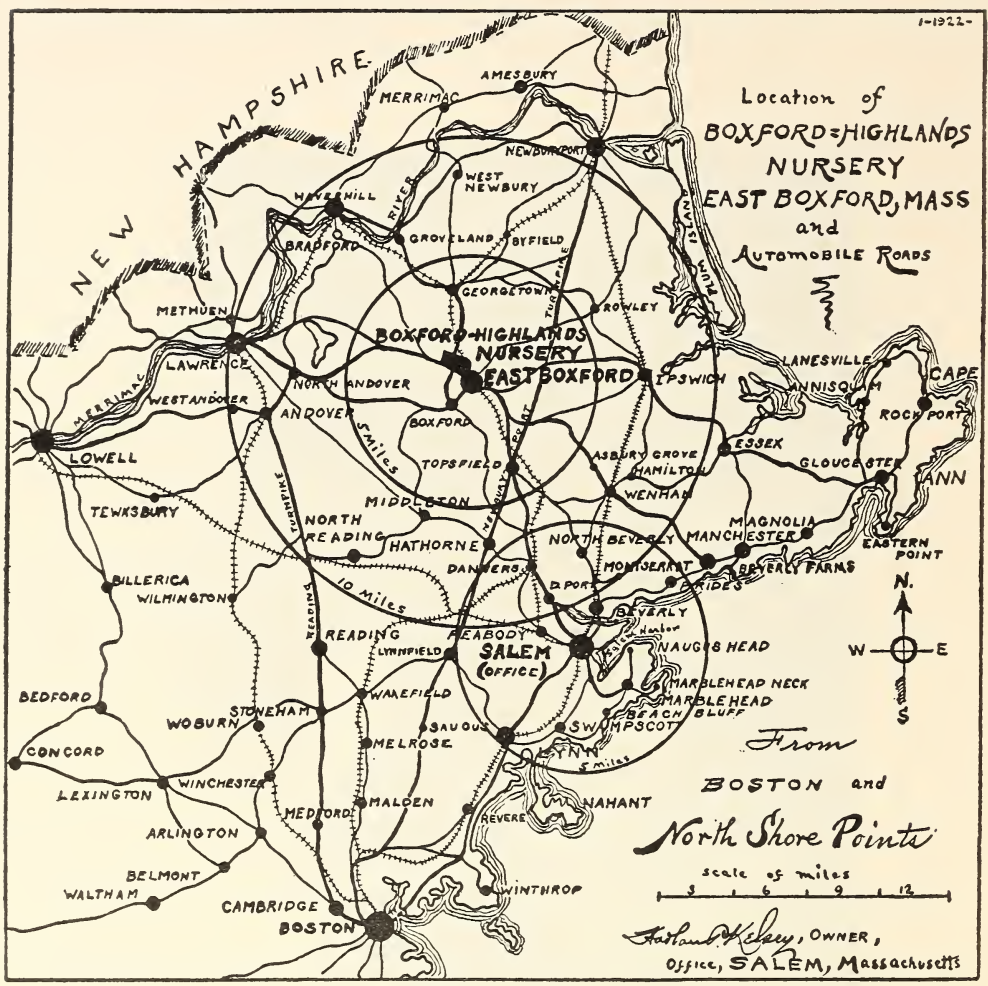

\section{How to reach Boxford-Highlands Nursery}

BOXFORD. HIGHLANDS NURSERY is located at EAST
BOXFORD, MASSACHUSETTS, 24 miles north of Boston, at Boxford Station, Georgetown Branch, B. \& M. R. R.

It is readily reached by good automobile roads from any part of New England. From Boston 28 miles, take either Newbury. port Turnpike turning West at Topsfield, or Reading Turnpike turning East at North Andover. Other distances are Salem, 13 miles; Lawrence, 11 miles; Haverhill, 9 miles; Newburyport, 10 miles; Manchester, 13 miles; Ipswich, 9 miles; Lowell, 20 miles. 


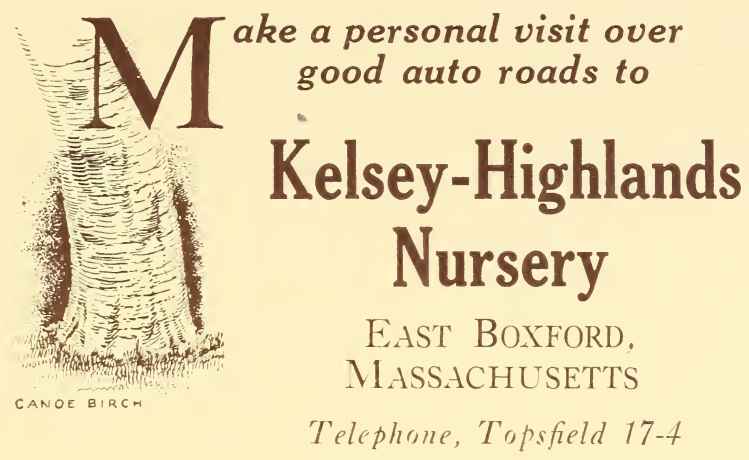

It is the only way to really learn how we grow the hundreds of thousands of beautiful specimen Rhododendrons, Kalmias, Hemlocks, Azaleas, Firs, Spruces, Flowering Crabs and other Specialties in choicest ornamentals which has made this Nursery famous.

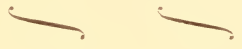

HARLAN P. KELSEY, Owner Hawthorne Building SALEM, MASSACHUSETTS Telephone, Salem 820 


$$
\begin{gathered}
1924 \\
\text { HARLAN P. KELSEY } \\
\text { BOXFORD-HIGHLANDS NURSERY } \\
\text { SALEM, MASS. }
\end{gathered}
$$

5 per cent discount may be deducted when cash accompanies order. When not taken, extra plants will be sent to cover such discount. 


\section{To HARLAN P. KELSEY}

SALEM, MASS.
Hardy American Plants and Specimen Evergreens

$$
\text { Post Office, }
$$
Date,

Dear Sir: Enclosed please find $\$$ for the belowe oriler selected from Calalog of your BOXFORD-HIGHLANDS NURSERY. Ship to

Give full shipping instructions unless you wish to leave to my best judgment. State whether by Freight, Express, Truck or Parcel Post. 'Take 5\% discount when pay'ment accompanies order; otherwise extra plants will be sent instead.

Send in time to arrive on or before.

$$
\text { Yours truly, }
$$

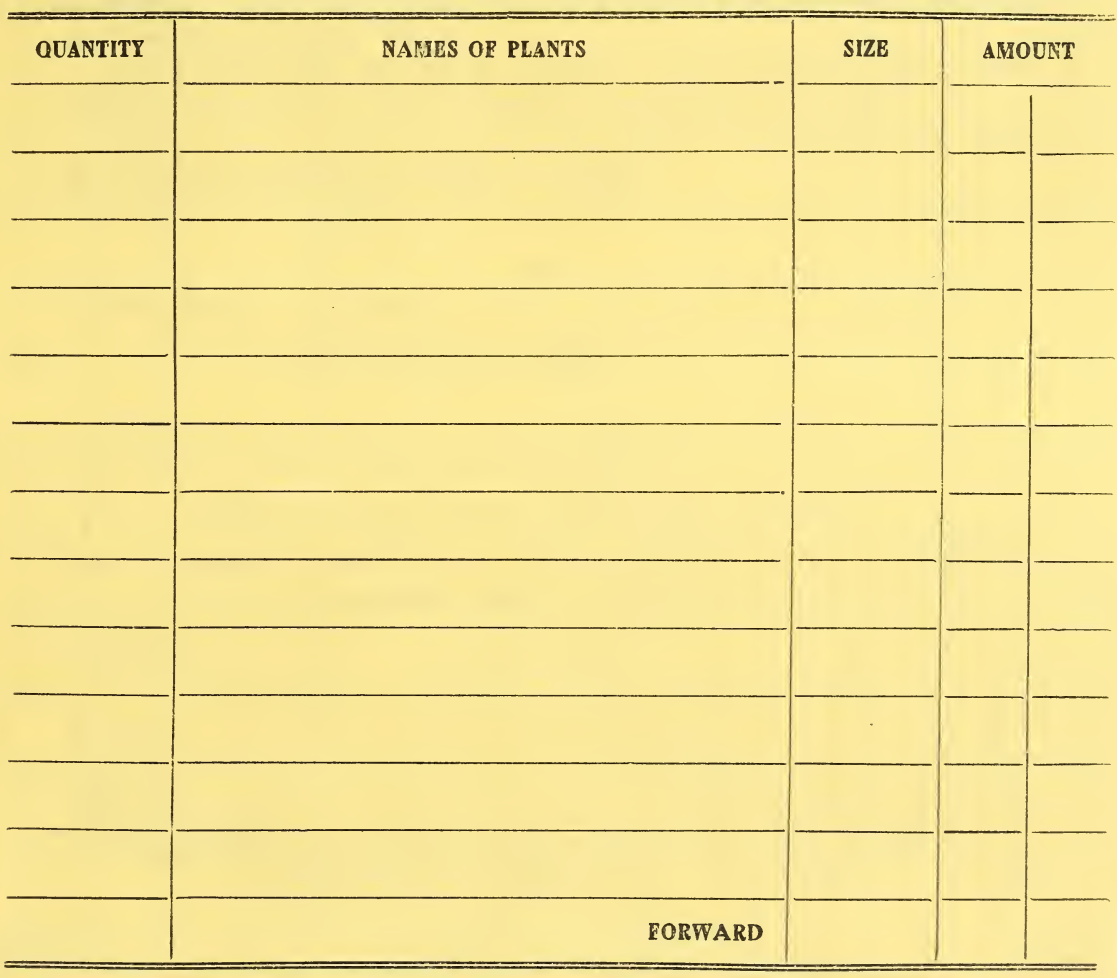




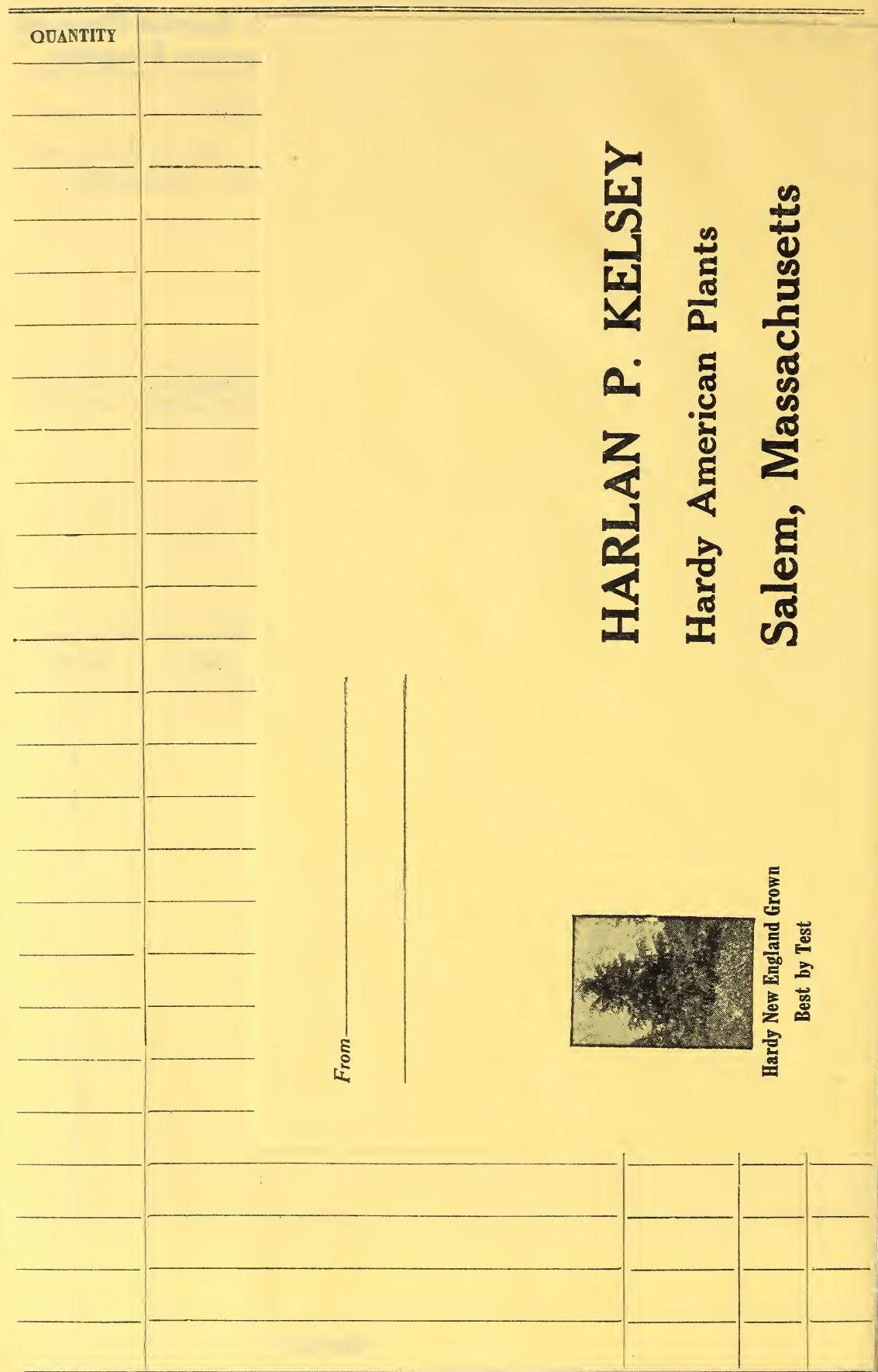




\section{Standardized Plant Names}

7 HIS new book is now rapidly being accepted as the standard authority for all dealings in, and current literature about plants in the United States. It is not a new and different scientific system of nomenclature, but a workable harmonization of the present confusion, and is the first co-operative attempt of the leading trade and amateur organizations to so standardize plant names as to make buying easy.

STANDARDIZED PLANT NAMES is published for the benefit and advantage of the American horticultural public, and sold at far below its actual cost-compilation costs and publishers' profits are wholly absent. The book contains 546 double column pages, covers more than 40,000 entries, and by the type arrangement shows the approved scientific and the approved common name for all plants in American commerce, as well as the unapproved synonyms. The sample page on the opposite side of this sheet shows the plan.

\section{Standardized Plant Names Is Available In Four Styles}

STANDARD EDITION, bound in cloth for library and general use, at $\$ 5$.

POCKET EDITION, flexibly bound in Fabrikoid, printed on India or "Bible" paper (weighs but II ounces, barely a half-inch thick, fits coat pocket easily), at $\$ 6.50$.

INTERLEAVED EDITION, which is the Standard edition with blank pages between the text pages for additions, at $\$ 6.50$.

These prices barely cover the actual cost of manufacture; there are no publisher's profits nor authors' royalties.

To HARLAN P. KELSEY,

\section{Date}

Secretary American Joint Committee on Horticultural Nomenclature Salem, Massachusetts

Please find enclosed for $\$$ for which you are to mail me Standardized Plant Names as follows: copies Standard Edition, cloth bound, at $\$ \tilde{5}$ each. copies Pocket Edition, India paper, flexibly bound, at $\$ 6.50$ each. copies Interleaved Edition, cloth bound, at $\$ 6.50$ each.

My Name is

Street State

"Standardized Plant Names" is sold by the Secretary only. It cannot be obtained from book stores or similar trade channels 
"Standardized Plant Names" is a cracker-jack-all that we have expected. This book will help us a lot along the way. I expect it to be about the most useful book in my office. It may not be any better than the Bible, but I will probably consult it oftener.-FRANK A. WAUgh, Amherst, Mass.

\section{STANDARDIZED PLANT NAMES}

BOLD-face, whether capitals or small letters, indicates approved scientific names.

ITALIC, whether capitals or small letters, indicates synonyms or unapproved names.

Small Capitals indicate approved common names.

Abbreviations: $\mathrm{Ag}=$ Economic Herbarium of the United States Department of Agriculture; Ar =Arnold Arboretum, Harvard University; Cy=Bailey's Standard Cyclopedia of Horticulture.

A dagger $(\dagger)$ indicates a horticultural variety for which the Joint Committee recommends the use of the common name alone, although recognizing that the scientific name in italics, followed by the dagger, has good botanical standing according to the authority cited.

\section{Aaronsbeard Cactus}

ABELIA Opuntia leucotricha chinensis (rupestris) ${ }^{\circ}$ CHINEst A engleriana . . . . ENGLer A. floribunda ... MEXICAN A. grandifiora . . . Glossy A. ABELMOSCHUS . . . HIBISCUS ABERIA . . . DOVYALIS ABIES

alba Ag-Ar A. pectinata

The name A. alba is often misapplied to Picea canadensis.

alcockiana... Picea alcockiana The name A. alcockiana has often been misapplied to Picea jezoensis hondoensis. amabilis

Cascade Fir

The name A. amabilis is sometimes misapplied to A. grandis.

apollinis . A. cephalonica apollinis arizonica (Abies lasiocarpa arizonica Cy) . . . . CORK FIR baborensis Cy . . . A. numidica balsamea .... Ballsam FIr -hudsonia (hudsonica). Hudson F. brachyphylla ... A. homolepis bracteata . . . . . A. venusta canadensis . Tsuga canadensis cephalonica . . . . GREeK FIR -apollinis . . . ApolLo F. cilicica . . . C CrlucIan F. concolor . . . White F. -lowiana . PAcific White F. See also hort. var. list on page 2.

douglasi. . Pseudotsuga douglasi excelsa . . . . . Picea excelsa firma (momi) . . . . MomI FIr fraseri...... Fraser F. grandis . . Great Silver F.
ABIES, continued

holophylla . . . . NeEdLe Fir homolepis (brachyphylla) . NIKко F. -umbilicata (umbellata)

Dimplecone $\mathrm{F}$. hudsonica . A. balsamea hudsonia lasiocarpa (subalpina). ALPINE FIR -arizonica $\mathrm{Cy}$. . . A. arizonica lowiana . . A. concolor lowiana magnifica . . . . RED FIK -shastensis . . . Shasta F. See also hort. var. list on page 2.

mariesi . . . Maries F. menziesi . . . Picea sitchensis momi . . . . . . . A. firma nobilis . . NOBLE FIr

See also hort. var. list on page 2.

nordmanniana ... NORDMANN F. numidica ( $A$. baborensis $\mathrm{Cy}$ )

AlgERIAN F. orientalis . . . Picea orientalis pectinata $(A$. picea $\mathrm{Cy} ; A$. alba Ag-Ar) . . . . Silver FIr See also hort. var. list on page 2 .

picea $\mathrm{Cy}$. . . . A. pectinata pindrow . . PINDROW FIR pinsapo . Spanish F. See also hort. var. list on page 2.

pungens . . . Picea pungens sachalinensis . SAKHALIN FIR sibirica . . Siberian F. spectabilis (A. webbiana $\mathrm{Cy}$ )

HIMALAYAN F. subalpina . . . A. lasiocarpa umbellata . A. homolepis umbilicata venusta (bracteata).

Bristlecone Fir veitchi . . . . . VEITCH F. webbiana $\mathrm{Cy}$. . A. spectabilis 

- . H. ARID.

AMERICAN PLANTS

SALEM, MASS.

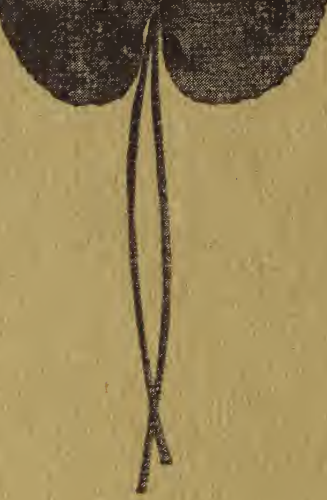

Member American Association of Nurserymen 